\title{
Effects of therapeutic probiotics on modulation of microRNAs
}

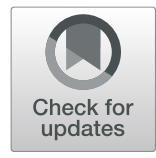

\author{
Amirhossein Davoodvandi ${ }^{1}$, Havva Marzban², Pouya Goleij ${ }^{3}$, Amirhossein Sahebkar ${ }^{4,5}$, Korosh Morshedi ${ }^{6}$, \\ Samaneh Rezaei ${ }^{7,8}$, Maryam Mahjoubin-Tehran ${ }^{7,8}$, Hossein Tarrahimofrad ${ }^{9}$, Michael R. Hamblin ${ }^{10^{*}}$ and \\ Hamed Mirzaei ${ }^{11^{*}}$
}

\begin{abstract}
Probiotics are beneficial bacteria that exist within the human gut, and which are also present in different food products and supplements. They have been investigated for some decades, due to their potential beneficial impact on human health. Probiotics compete with pathogenic microorganisms for adhesion sites within the gut, to antagonize them or to regulate the host immune response resulting in preventive and therapeutic effects. Therefore, dysbiosis, defined as an impairment in the gut microbiota, could play a role in various pathological conditions, such as lactose intolerance, gastrointestinal and urogenital infections, various cancers, cystic fibrosis, allergies, inflammatory bowel disease, and can also be caused by antibiotic side effects. MicroRNAs (miRNAs) are short non-coding RNAs that can regulate gene expression in a post-transcriptional manner. miRNAs are biochemical biomarkers that play an important role in almost all cellular signaling pathways in many healthy and disease states. For the first time, the present review summarizes current evidence suggesting that the beneficial properties of probiotics could be explained based on the pivotal role of miRNAs.
\end{abstract}

Keywords: MicroRNAs, Probiotics, Biomarkers, Cancer, Inflammatory bowel disease, Supplements

\section{Background}

The gastrointestinal tract (GIT) is an active ecosystem within the human body, and normally contains beneficial bacteria essential for maintaining metabolism and immune cell maturation. In the gut, healthy bacteria are part of the normal microbiota that arrive in the intestine via food intake, and naturally coexist with each other. These microorganisms are in a balanced relationship with immune cells associated with the lamina propria in the gut, and lead to the stimulation and maturation of these immune cells [1].

\footnotetext{
* Correspondence: HAMBLIN1@helix.mgh.harvard.edu; mirzaei-h@kaums.ac.ir; h.mirzaei2002@gmail.com

${ }^{10}$ Wellman Center for Photomedicine, Massachusetts General Hospital, Harvard Medical School, 40 Blossom Street, Boston, MA 02114, USA

${ }^{11}$ Research Center for Biochemistry and Nutrition in Metabolic Diseases, Institute for Basic Sciences, Kashan University of Medical Sciences, Kashan, Iran

Full list of author information is available at the end of the article
}

Probiotics are defined as a group of beneficial living bacteria, which are naturally members of the intestinal microbiota, and some of them have been incorporated into food products and supplements to improve GIT health through maintaining a good microbial balance. To improve host health or to treat various infectious and non-infectious diseases, the potential properties of probiotics have been widely explored in experimental models. The mentioned beneficial effects include: a decrease in GIT inflammatory responses [2], preventive activity against malignancy [3-5], protective role against infections [6-8], allergy prevention $[9,10]$, inhibition of Helicobacter pylori growth [11], and relief of irritable bowel syndrome [12]. In addition, the antioxidant, antiinflammatory and anticancer activity of probiotics may be explained by saturated fatty acid production in the gut $[13,14]$. Although probiotics have shown encouraging results in several human diseases, such as irritable 
bowel syndrome, multi-drug resistant pathogens, and diabetes [15-17], more extensive studies are still needed to confirm their preliminary effectiveness on nutrition, human health, and modulation of various diseases.

MicroRNAs (miRNAs) are members of the family of non-coding RNAs, and are 19-25, nucleotides in length [18]. miRNAs are generated from endogenous primary miRNA precursors [19]. Recently, interest in miRNAs has taken off due to their roles in the treatment and development of a wide variety of diseases. Additionally, miRNAs play key roles in numerous normal physiological networks. Deregulation of miRNAs has been implicated in the pathogenesis of several disorders, including cancer and infections [20,21].

This review summarizes the available data on the modulatory effects of probiotics on miRNA expression and function in pathological conditions,

\section{Probiotics in health and disease}

Microbial populations found within the GIT, have numerous roles in different aspects of human health [22]. Any change in the normal microbiome can be the cause of various diseases, including gastrointestinal cancers and obesity $[23,24]$. Probiotics are externally administered living microbes that are beneficial for human health via their regulatory function on the host GI microbiome, host immune system, and systemic inflammation [25-27]. Probiotics, if administered in a sufficient amount, can improve diseases, or the lessen the complications of various disorders, including GI cancers, inflammatory bowel disease (IBD), rheumatoid arthritis, obesity, and diabetes (Table 1) [106, 107]. Lactobacillus and Bifidobacterium species are the major bacterial strains that are generally consumed as probiotics [107].

The major mechanisms of action of probiotics, include enhancement of the gut epithelial barrier, adhesion to intestinal mucosa, and concomitant inhibition of pathogen adhesion, competitive exclusion of pathogenic microorganisms, production of anti-microbial substances, and modulation of the immune system (Fig. 1).

Epidemiological studies clearly show that, despite all the advances made in the field of diagnosis, prevention and treatment of cancer, the prevalence of cancer is still increasing. About $80 \%$ of all types of cancer are due to environmental and lifestyle factors [108]. Due to the high burden of cancer around the world, effective treatment cancer is very important [109]. There are many treatment methods such as chemotherapy, radiotherapy, targeted therapy and immunotherapy, but their overall efficacy is still not satisfactory $[110,111]$. Probiotics have recently been used to improve cancer treatment, relieve symptoms and increase the quality of life [112]. One of the reasons for the occurrence of cancers, in particular GIT cancers, may be changes in the normal GI microbial flora, and therefore the use probiotics is attractive to modulate these changes, reduce complications, or even treat cancer [113]. In one study by Gao et al., probiotic therapy reduced the number of mucosal-associated pathogens in patients with colorectal cancer (CRC) by altering the profile of microbial flora in the mucosa. A total of 22 CRC patients completed the trial. Patients were randomized into a PGT group $(n=11)$ taking probiotics or CGT group $(n=11)$ taking preoperative placebo. It should be noted that the participants in the PGT group took an encapsulated probiotic combination consisting of living Bifidobacterium longum, Enterococcus faecalis, and Lactobacillus acidophilus (1:1:1) with at least $1 \times 10^{7}$ $\mathrm{CFU} / \mathrm{g}$ viable cells, 3 times a day, with a total daily dosage of $6 \times 10^{7} \mathrm{CFU}$ for 5 days. The participants in the CGT group took only encapsulated maltodextrin 3 times a day. The results showed that the probiotic supplement regimen could efficiently modify the composition and diversity of the gut microflora. It could also suppress specific potential pathogens such as Peptostreptococcus and Fusobacterium strains. In addition, probiotics enhanced the numbers of specific beneficial microorganisms [114]. Abnormal blood vessels and hypoxic and necrotic regions are common features of solid tumors and related to the malignant phenotype and therapy resistance. Certain obligate or facultative anaerobic bacteria exhibit inherent ability to colonize and proliferate within solid tumors in vivo. Escherichia coli Nissle 1917, a nonpathogenic probiotic in European markets, has been known to proliferate selectively in the interface between the viable and necrotic regions of solid tumors. $\mathrm{Li}$ et al. established a tumor-targeting therapy system using the genetically engineered E. coli Nissle 1917 for targeted delivery of cytotoxic compounds, including glidobactin, colibactin, and luminmide. Biosynthetic gene clusters of these cytotoxic compounds were introduced into E. coli Nissle 1917 and the corresponding compounds were detected in the resultant recombinant strains. The recombinant E. coli Nissle 1917 showed cytotoxic activity in vitro and in vivo as well, and suppressed the tumor growth [115]. Another study was conducted to evaluate the effect of probiotic supplementation in patients with laryngeal cancer. After the intervention, biochemical markers of stress were reduced. A total of 20 healthy controls and 30 patients with laryngeal cancer were included. Then, for two weeks prior to the surgical operation, 20 patients were randomly assigned to take a placebo or probiotic supplement (Clostridium butyricum; $420 \mathrm{mg} /$ capsule) two times per day. In addition, the degree of anxiety and the heart rate were assessed. It was found that the level of serum corticotropin-releasing factor (CRF) in patients with laryngeal cancer was increased as they approached the time of surgery, but no corresponding increase in CRF, anxiety or heart rate was 
Table 1 Selected probiotic preparations that have been investigated to treat various diseases

\begin{tabular}{|c|c|c|c|c|c|c|c|}
\hline $\begin{array}{l}\text { Physiology or pathological } \\
\text { condition }\end{array}$ & Probiotic agent & $\begin{array}{l}\text { Probiotic } \\
\text { concentration }\end{array}$ & $\begin{array}{l}\text { Duration } \\
\text { of study }\end{array}$ & Effect (s) & Model & $\begin{array}{l}\text { Sample } \\
\text { (n) }\end{array}$ & Ref \\
\hline Colorectal cancer & $\begin{array}{l}\text { Lactobacillus acidophilus, } \\
\text { L. rhamnosus }\end{array}$ & $\begin{array}{l}2 \times 10^{9} \mathrm{CFU} \\
\text { (colony-forming units) }\end{array}$ & 12 weeks & $\begin{array}{l}\text { Enhance bowel signs } \\
\text { and QOL }\end{array}$ & Human & 28 & [28] \\
\hline Gastric cancer & $\begin{array}{l}\text { Bifidobacterium infantis, } \\
\text { Lactobacillus acidophilus, } \\
\text { Enterococcus faecalis, } \\
\text { Bacillus cereus }\end{array}$ & $>10^{6} \mathrm{CFU} /$ tablet & 6-7 days & $\begin{array}{l}\text { Improve immune response } \\
\text { and decrease severity of } \\
\text { inflammation }\end{array}$ & Human & 50 & [29] \\
\hline Colorectal cancer & $\begin{array}{l}\text { Lactobacillus acidophilus, } \\
\text { L. casei, L. lactis, } \\
\text { Bifidobacterium bifidum, } \\
\text { B. longum, B. infantis }\end{array}$ & $3 \times 10^{10} \mathrm{CFU}$ & 8 weeks & $\begin{array}{l}\text { Improve QOL, decrease } \\
\text { inflammatory biomarkers, } \\
\text { reduce side effects of } \\
\text { chemotherapy }\end{array}$ & Human & 70 & [30] \\
\hline Colorectal cancer & $\begin{array}{l}\text { Lactobacillus acidophilus, } \\
\text { L. casei. L. lactis, Bifidobacterium } \\
\text { bifidum, B. Iongum, B. infantis }\end{array}$ & $3 \times 10^{10} \mathrm{CFU}$ & 1 week & $\begin{array}{l}\text { Accelerate return of } \\
\text { normal gut function }\end{array}$ & Human & 20 & [31] \\
\hline Asthma & $\begin{array}{l}\text { Lactobacillus rhamnosus GG } \\
(\mathrm{LGG)}\end{array}$ & $1 \times 10^{10} \mathrm{CFU}$ & 6 months & $\begin{array}{l}\text { Enhance T-regulatory } \\
\text { induction }\end{array}$ & Human & 10 & [32] \\
\hline Eczema and Asthma & $\begin{array}{l}\text { Lactobacillus rhamnosus } \\
\mathrm{GG}(\mathrm{LGG})\end{array}$ & $1 \times 10^{10} \mathrm{CFU}$ & 6 months & $\begin{array}{l}\text { Prevent the eczema or } \\
\text { asthma development }\end{array}$ & Human & 92 & [33] \\
\hline $\begin{array}{l}\text { Seasonal allergic rhinitis and } \\
\text { Intermittent asthma }\end{array}$ & $\begin{array}{l}\text { Bifidobacterium spp } \\
\text { (B. longum BB536, } \\
\text { B. infantis M-63, B. } \\
\text { breve M-16V) }\end{array}$ & $\begin{array}{l}3 \times 10^{9} \mathrm{CFU} \\
1 \times 10^{9} \mathrm{CFU} \text { and } \\
1 \times 10^{9} \mathrm{CFU}\end{array}$ & 4 weeks & Enhance AR and QOL & Human & 40 & [34] \\
\hline Atopic & $\begin{array}{l}\text { Bifidobacterium bifidumW23, } \\
\text { Bifi-dobacterium lactisW52 and } \\
\text { Lactococcus Lactis W58 }\end{array}$ & $3 \times 10^{9} \mathrm{CFU}$ & 6 years & $\begin{array}{l}\text { Minor impact on gut } \\
\text { microbiota composition }\end{array}$ & Human & 99 & [35] \\
\hline Necrotizing enterocolitis (NEC) & Bifidobacterium and Lactobacillus & $3 \times 10^{9} \mathrm{CFU}$ & $\begin{array}{l}\text { At least } 10 \\
\text { days }\end{array}$ & $\begin{array}{l}\text { Decreased frequency of } \\
\text { necrotizing enterocolitis } \\
\text { in preterm neonates }\end{array}$ & Human & 52 & [36] \\
\hline Necrotizing enterocolitis (NEC) & $\begin{array}{l}\text { Bifidobacterium lactis and } \\
\text { Lactobacillus rhamnosus }\end{array}$ & $\begin{array}{l}1 \times 10^{8} \mathrm{CFU} \text { and } \\
1 \times 10^{9} \mathrm{CFU}\end{array}$ & 3 years & No significant effects & Human & 332 & [37] \\
\hline Necrotizing enterocolitis (NEC) & $\begin{array}{l}\text { Lactobacillus acidophilus and } \\
\text { Bifidobacterium bifidum }\end{array}$ & $\begin{array}{l}1 \times 10^{9} \mathrm{CFU} \text { and } \\
1 \times 10^{9} \mathrm{CFU}\end{array}$ & 8 month & No significant effects & Human & 31 & [38] \\
\hline $\begin{array}{l}\text { Inflammatory bowel disease } \\
\text { (IBD) }\end{array}$ & $\begin{array}{l}\text { Lactobacillus rhamnosus GR-1 } \\
\text { and Lactobacillus reuteri RC-14 }\end{array}$ & $\begin{array}{l}1 \times 10^{3} \mathrm{CFU} \\
\text { and } 2 \times 10^{7} \mathrm{CFU}\end{array}$ & 30 days & $\begin{array}{l}\text { Anti-inflammatory } \\
\text { effects }\end{array}$ & Human & 8 & [39] \\
\hline $\begin{array}{l}\text { Inflammatory bowel disease } \\
\text { (IBD) }\end{array}$ & $\begin{array}{l}\text { Lactobacillus acidophilus La-5 } \\
\text { and Bifidobacterium BB-12 }\end{array}$ & $1 \times 10^{6} \mathrm{CFU}$ & 8 weeks & $\begin{array}{l}\text { Enhanced intestinal } \\
\text { function }\end{array}$ & Human & 105 & [40] \\
\hline Rheumatoid arthritis (RA) & $\begin{array}{l}\text { Lactobacillus rhamnosus } \\
\text { GR-1 and Lactobacillus } \\
\text { reuteri RC-14 }\end{array}$ & $2 \times 10^{9} \mathrm{CFU}$ & 4 month & No significant effects & Human & 14 & [41] \\
\hline Rheumatoid arthritis & $\begin{array}{l}\text { Lactobacillus acidophilus, } \\
\text { L. casei and Bifidobacterium } \\
\text { bifidum }\end{array}$ & $6 \times 10^{9} \mathrm{CFU}$ & 8 weeks & Therapeutic effects & Human & 30 & [42] \\
\hline Rheumatoid arthritis & Lactobacillus casei 01 & $1 \times 10^{8} \mathrm{CFU}$ & 8 weeks & $\begin{array}{l}\text { Reduced disease } \\
\text { activity and inflammatory } \\
\text { status }\end{array}$ & Human & 22 & [43] \\
\hline Atopic dermatitis & Lactobacillus rhamnosus (LR) & NA & 8 weeks & $\begin{array}{l}\text { Reduce signs of atopic } \\
\text { dermatitis }\end{array}$ & Human & 30 & [44] \\
\hline Atopic dermatitis & Lactobacillus plantarum IS-10506 & $1 \times 10^{10} \mathrm{CFU}$ & 12 weeks & Therapeutic effects & Human & 12 & [45] \\
\hline Atopic dermatitis (AD) & $\begin{array}{l}\text { Lactobacillus rhamnosus GG } \\
\text { (LGG), Bifidobacterium animalis } \\
\text { subsp. lactis Bb-12 (Bb-12), } \\
\text { d L. acidophilus La-5 (La-5) }\end{array}$ & $\begin{array}{l}5 \times 10^{10} \mathrm{CFU}, 5 \times \\
10^{10} \mathrm{CFU} \text { and } 5 \times \\
10^{9} \mathrm{CFU}\end{array}$ & 2 years & $\begin{array}{l}\text { Decreased proportion } \\
\text { of Th22 cells. }\end{array}$ & Human & 68 & [46] \\
\hline Irritable bowel syndrome (IBS) & $\begin{array}{l}\text { Bacillus subtilis, Bifidobacterium } \\
\text { spp., Lactobacillus spp., L. lactis, } \\
\text { and Streptococcus thermophilus }\end{array}$ & $8 \times 10^{9} \mathrm{CFU}$ & 16 weeks & $\begin{array}{l}\text { Significantly improvement } \\
\text { in IBS symptoms well } \\
\text { tolerance }\end{array}$ & Human & 181 & [47] \\
\hline Irritable bowel syndrome (IBS) & $\begin{array}{l}\text { Lactobacillus acidophilus CL1285, } \\
\text { L. casei LBC80R, L. rhamnosus CLR2 }\end{array}$ & $5 \times 10^{10} \mathrm{CFU}$ & 12 weeks & $\begin{array}{l}\text { Improved stool consistency } \\
\text { and frequency, QOL, and } \\
\text { IBS symptoms }\end{array}$ & Human & 76 & [48] \\
\hline Irritable bowel syndrome (IBS) & Bifidobacterium longum (BL) & $1 \times 10^{10} \mathrm{CFU}$ & 6 weeks & Decreased depression & Human & 18 & [49] \\
\hline Irritable bowel syndrome (IBS) & Lactobacillus brevis KB290 & $1 \times 10^{9} \mathrm{CFU}$ & 12 weeks & $\begin{array}{l}\text { Improved symptoms } \\
\text { and inflammatory status }\end{array}$ & Human & 20 & [50] \\
\hline Gastroenteritis & Lactobacillus rhamnosus GG & $1 \times 10^{10} \mathrm{CFU}$ & 5 days & No significant effects & Human & 468 & [51] \\
\hline
\end{tabular}


Table 1 Selected probiotic preparations that have been investigated to treat various diseases (Continued)

\begin{tabular}{|c|c|c|c|c|c|c|c|}
\hline $\begin{array}{l}\text { Physiology or pathological } \\
\text { condition }\end{array}$ & Probiotic agent & $\begin{array}{l}\begin{array}{l}\text { Probiotic } \\
\text { concentration }\end{array} \\
\end{array}$ & $\begin{array}{l}\text { Duration } \\
\text { of study }\end{array}$ & Effect (s) & Model & $\begin{array}{l}\text { Sample } \\
\text { (n) }\end{array}$ & Ref \\
\hline Acute gastroenteritis (AGE) & Lactobacillus rhamnosus (LGG) & $\begin{array}{l}1 \times 10^{10} \mathrm{CFU} \\
\text { (twice a day) }\end{array}$ & 5 days & - & Human & - & {$[52]$} \\
\hline Gastroenteritis & Lactobacillus rhamnosus GG (LGG) & $1 \times 10^{10} \mathrm{CFU}$ & 4 weeks & $\begin{array}{l}\text { Immuno-modulatory } \\
\text { effects }\end{array}$ & Human & 65 & [53] \\
\hline Eczema & $\begin{array}{l}\text { Lactobacillus salivarius CUL61, } \\
\text { L. paracasei } \\
\text { CUL08, Bifidobacterium animalis } \\
\text { subspecies lactis CUL34 and } \\
\text { B. bifidum CUL20 }\end{array}$ & $1 \times 10^{10} \mathrm{CFU}$ & 2 years & Prevent eczema & Human & 187 & {$[54]$} \\
\hline Eczema & $\begin{array}{l}\text { Bifidobacterium longum (BL999) } \\
\text { and Lactobacillus rhamnosus (LPR) }\end{array}$ & NA & 5 years & No significant effects & Human & 124 & {$[55]$} \\
\hline Allergic rhinitis & Bifidobacterium lactis NCC 2818 & $4 \times 10^{9} \mathrm{CFU}$ & 8 weeks & $\begin{array}{l}\text { Improved immune } \\
\text { parameters and allergic } \\
\text { symptoms }\end{array}$ & Human & 10 & {$[56]$} \\
\hline Allergic rhinitis & Lactobacillus paracasei LP-33 & $2 \times 10^{9} \mathrm{CFU}$ & 5 weeks & Enhanced QOL & Human & 179 & {$[57]$} \\
\hline Allergic rhinitis & $\begin{array}{l}\text { Lactobacillus paracasei HF.A00232 } \\
\text { (LP) }\end{array}$ & $5 \times 10^{9} \mathrm{CFU}$ & 8 weeks & No significant effects & Human & 32 & {$[58]$} \\
\hline Celiac disease & Bifidobacterium longum CECT 7347 & $1 \times 10^{9} \mathrm{CFU}$ & 3 months & Enhanced health status & Human & 17 & {$[59]$} \\
\hline Celiac disease & Bifidobacterium infantis & $2 \times 10^{9} \mathrm{CFU}$ & 3 weeks & - & Human & 12 & {$[60]$} \\
\hline Celiac disease & Bifidobacterium breve BR03 and B632 & $1 \times 10^{9} \mathrm{CFU}$ & 3 month & Reduced TNF-a levels & Human & 22 & [61] \\
\hline Obesity & Lactobacillus casei strain Shirota (LCS) & $\geq 4 \times 10^{10} \mathrm{CFU}$ & 6 months & $\begin{array}{l}\text { Decreased body weight } \\
\text { and increased high density } \\
\text { lipoprotein cholesterol } \\
\text { concentration }\end{array}$ & Human & 12 & [62] \\
\hline Obesity & Lactobacillus rhamnosus (LPR) & $1.6 \times 10^{8} \mathrm{CFU}$ & 12 weeks & $\begin{array}{l}\text { Improve fasting fullness and } \\
\text { cognitive restraint in men }\end{array}$ & Human & 62 & {$[63]$} \\
\hline Obesity & $\begin{array}{l}\text { Lactobacillus curvatus HY7601, } \\
\text { L. plantarum KY1032 }\end{array}$ & $5 \times 10^{9} \mathrm{CFU}$ & 12 weeks & $\begin{array}{l}\text { Induced weight loss and } \\
\text { decreased adiposity. }\end{array}$ & Human & 32 & {$[64]$} \\
\hline $\begin{array}{l}\text { Type I diabetes and Type II } \\
\text { diabetes }\end{array}$ & $\begin{array}{l}\text { Lactobacillus acidophilus ZT-L1, } \\
\text { Bifidobacterium bifidum ZT-B1, L. } \\
\text { reuteri ZT-Lre, L. fermentum ZT-L3 }\end{array}$ & $8 \times 10^{9} \mathrm{CFU}$ & 12 weeks & $\begin{array}{l}\text { Beneficial effects on glycemic } \\
\text { control and markers of } \\
\text { cardio-metabolic risk. }\end{array}$ & Human & 30 & {$[65]$} \\
\hline Type II diabetes & $\begin{array}{l}\text { Bifidobacterium bifidum W23, } \\
\text { B. lactis W52, L. acidophilus W37, L. } \\
\text { brevis W63, L. casei W56, L. salivarius } \\
\text { W24, Lactococcus lactis W19 and } \\
\text { L.s lactis W58 }\end{array}$ & $2.5 \times 10^{9} \mathrm{CFU}$ & 12 weeks & Enhanced HOMA-IR & Human & 39 & {$[66]$} \\
\hline Type II diabetes & Lactobacillus reuteri DSM 17938 & $1 \times 10^{8} \mathrm{CFU}$ & 12 weeks & No significant effects & Human & 30 & {$[67]$} \\
\hline Type II diabetes & $\begin{array}{l}\text { concentrated biomass of } 14 \text { probiotic } \\
\text { bacteria genera } \\
\text { Bifidobacterium, Lactobacillus, } \\
\text { Lactococcus, Propionibacterium }\end{array}$ & $\begin{array}{l}\text { Lactobacillus + } \\
\text { Lactococcus } \\
\left(6 \times 10^{10} \mathrm{CFU} / \mathrm{g}\right), \\
\text { Bifidobacterium } \\
\left(1 \times 10^{10} / \mathrm{g}\right) \\
\text { Propionibacterium } \\
\left(3 \times 10^{10} / \mathrm{g}\right) \text { and } \\
\text { Acetobacter } \\
\left(1 \times 10^{6} / \mathrm{g}\right)\end{array}$ & 8 weeks & $\begin{array}{l}\text { Reversed insulin } \\
\text { resistance }\end{array}$ & Human & 31 & {$[68]$} \\
\hline Type II diabetes & $\begin{array}{l}\text { Lactobacillus acidophilus La-5 } \\
\text { and Bifidobacterium animalis } \\
\text { subsp lactis BB-12 }\end{array}$ & $1 \times 10^{9} \mathrm{CFU}$ & 6 weeks & $\begin{array}{l}\text { Enhanced glycemic control } \\
\text { in T2D patients, however, } \\
\text { the intake of fermented } \\
\text { milk seems to be involved } \\
\text { with other metabolic } \\
\text { changes, such as } \\
\text { reduced inflammatory } \\
\text { cytokines (TNF-a and } \\
\text { resistin). }\end{array}$ & Human & 23 & {$[69]$} \\
\hline HIV & Lactobacillus casei Shirota (LCS) & $6.5 \times 10^{8} \mathrm{CFU}$ & 8 weeks & $\begin{array}{l}\text { Immunological and } \\
\text { virological effects }\end{array}$ & Human & 20 & {$[70]$} \\
\hline HIV & $\begin{array}{l}\text { Lactobacillus plantarum, Streptococcus } \\
\text { thermophilus, Bifidobacterium } \\
\text { breve, L. paracasei, } \\
\text { L. delbrueckii subsp. bulgaricus, } \\
\text { L. acidophilus, } \\
\text { B. longum, } \\
\text { B. infantis }\end{array}$ & $1.8 \times 10^{12} \mathrm{CFU}$ & 6 months & $\begin{array}{l}\text { Beneficial effects on the } \\
\text { reconstitution of physical } \\
\text { and immunological } \\
\text { integrity of the mucosal } \\
\text { intestinal barrier }\end{array}$ & Human & 10 & [71] \\
\hline
\end{tabular}


Table 1 Selected probiotic preparations that have been investigated to treat various diseases (Continued)

\begin{tabular}{|c|c|c|c|c|c|c|c|}
\hline $\begin{array}{l}\text { Physiology or pathological } \\
\text { condition }\end{array}$ & Probiotic agent & $\begin{array}{l}\text { Probiotic } \\
\text { concentration }\end{array}$ & $\begin{array}{l}\text { Duration } \\
\text { of study }\end{array}$ & Effect (s) & Model & $\begin{array}{l}\text { Sample } \\
\text { (n) }\end{array}$ & Ref \\
\hline HIV & Saccharomyces boulardii & NA & 12 weeks & Therapeutic effects & Human & 22 & [72] \\
\hline $\begin{array}{l}\text { Non-alcoholic fatty liver } \\
\text { disease }\end{array}$ & $\begin{array}{l}\text { a mixture of eight probiotic strains } \\
\text { (Streptococcus thermophilus, } \\
\text { bifidobacteria SPP., Lactobacillus } \\
\text { acidophilus, L. plantarum, L. paracasei, } \\
\text { and L. delbrueckii subsp. bulgaricus) }\end{array}$ & NA & 4 month & $\begin{array}{l}\text { Reduced body mass } \\
\text { index (BMI) in probiotic } \\
\text { supplemented children }\end{array}$ & Human & 22 & [73] \\
\hline $\begin{array}{l}\text { Non-alcoholic fatty liver } \\
\text { disease }\end{array}$ & $\begin{array}{l}\text { Lactobacillus acidophilus La5 } \\
\text { and Bifidobacterium lactis Bb12 }\end{array}$ & $\begin{array}{l}6.46 \times 10^{6} \text { and } \\
4.97 \times 10^{6} \mathrm{CFU} / \mathrm{g}\end{array}$ & 8 weeks & $\begin{array}{l}\text { Improved } \\
\text { hepatic enzymes, serum } \\
\text { total cholesterol, and } \\
\text { low density lipoprotein } \\
\text { cholesterol levels }\end{array}$ & Human & 36 & [74] \\
\hline $\begin{array}{l}\text { Non-alcoholic fatty liver } \\
\text { disease }\end{array}$ & $\begin{array}{l}\text { Lactobacillus } \\
\text { casei, L. acidophilus, L. rhamnosus, } \\
\text { L. bulgaricus, Bifidobacterium breve, } \\
\text { B. longum, and Streptococcus } \\
\text { thermophilus. }\end{array}$ & $\begin{array}{l}\text { Lactobacillus casei } \\
\left(3 \times 10^{9} \mathrm{CFU} / \mathrm{g}\right) \text {, } \\
\text { Lactobacillus acidophilus } \\
\left(3 \times 10^{10} \mathrm{CFU} /\right. \\
\text { g), Lactobacillus } \\
\text { rhamnosus } \\
\left(7 \times 10^{9} \mathrm{CFU} / \mathrm{g}\right) \text {, } \\
\text { Lactobacillus bulgaricus } \\
\left(5 \times 10^{8} \mathrm{CFU} / \mathrm{g}\right) \text {, } \\
\text { Bifidobacterium breve } \\
\left(2 \times 10^{10} \mathrm{CFU} / \mathrm{g}\right) \text {, } \\
\text { Bifidobacterium longum } \\
\left(1 \times 10^{9} \mathrm{CFU} / \mathrm{g}\right) \text {, and } \\
\text { Streptococcus } \\
\text { thermophilus } \\
\left(3 \times 10^{8} \mathrm{CFU} / \mathrm{g}\right) \text {. }\end{array}$ & 8 weeks & $\begin{array}{l}\text { Reduced insulin } \\
\text { requirement, reversed } \\
\text { insulin resistance, TNF-a, } \\
\text { and IL-6 }\end{array}$ & Human & 21 & [75] \\
\hline Non-alcoholic steatohepatitis & $\begin{array}{l}\text { Lactobacillus casei, L. rhamnosus, } \\
\text { L. bulgaris, } \\
\text { Bifidobacterium longum, and } \\
\text { Streptococcus thermophilus }\end{array}$ & $1 \times 10^{8} \mathrm{CFU}$ & 12 weeks & $\begin{array}{l}\text { Reduced body mass } \\
\text { index (BMI) and serum } \\
\text { cholesterol }\end{array}$ & Human & 38 & [76] \\
\hline Non-alcoholic steatohepatitis & $\begin{array}{l}\text { Lactobacillus plantarum, } \\
\text { L. deslbrueckii, L. acidophilus, } \\
\text { L. rhamnosus and Bifidobacterium } \\
\text { bifidum }\end{array}$ & $2 \times 10^{8} \mathrm{CFU}$ & 6 months & $\begin{array}{l}\text { No changes in body mass } \\
\text { index, waist circumference, } \\
\text { glucose or lipid levels but } \\
\text { decreased liver fat and } \\
\text { aspartate transaminase } \\
\text { (AST) level }\end{array}$ & Human & 10 & [77] \\
\hline Urinary Tract Infections & Lactobacillus crispatus GAI 98322 & $1 \times 10^{8} \mathrm{CFU}$ & 1 year & Prevent recurrence of UTI & Human & 9 & [78] \\
\hline Urinary Tract Infections & Lactobacillus crispatus & $1 \times 10^{8} \mathrm{CFU}$ & 10 weeks & Less recurrence of UTI & Human & 43 & [79] \\
\hline Urinary Tract Infections & Lactobacillus GG & $6 \times 10^{9} \mathrm{CFU}$ & 1 week & $\begin{array}{l}\text { Decreased incidence of } \\
\text { UTIs, necrotizing } \\
\text { enterocolitis (NEC) } \\
\text { and sepsis }\end{array}$ & Human & 295 & [80] \\
\hline Urinary Tract Infections & Lactobacillus crispatus CTV-05 & $5 \times 10^{8} \mathrm{CFU}$ & 5 days & Minimal side effects & Human & 15 & [81] \\
\hline Vaccine Adjuvants & $\begin{array}{l}\text { Bifidobacterium lactis, Lactobacillus } \\
\text { acidophilus, L. plantarum, } \\
\text { L. paracasei and L. salivarius }\end{array}$ & $2 \times 10^{10} \mathrm{CFU}$ & 3 weeks & $\begin{array}{l}\text { Faster immune response. } \\
\text { Specific probiotics may } \\
\text { be adjuvants to humoral } \\
\text { immune response following } \\
\text { oral vaccination }\end{array}$ & Human & 63 & [82] \\
\hline Vaccine Adjuvants & Lactobacillus fermentum CECT5716 & $1 \times 10^{10} \mathrm{CFU}$ & 4 weeks & $\begin{array}{l}\text { Potentiated the immunologic } \\
\text { response and improved } \\
\text { systemic protection from } \\
\text { infection }\end{array}$ & Human & 25 & [83] \\
\hline Vaccine Adjuvants & Lactobacillus GG & $1 \times 10^{10} \mathrm{CFU}$ & 4 weeks & $\begin{array}{l}\text { Improved influenza } \\
\text { vaccine immunogenicity }\end{array}$ & Human & 19 & [84] \\
\hline Plaque and carries & Lactobacillus reuteri & $1 \times 10^{8} \mathrm{CFU}$ & 1 years & $\begin{array}{l}\text { Decreased caries prevalence } \\
\text { and gingivitis score }\end{array}$ & Human & 60 & [85] \\
\hline Plaque and carries & $\begin{array}{l}\text { Streptococcus uberis } \mathrm{KJ}^{\mathrm{TM}}, \\
\text { Streptococcus. oralis } \mathrm{KJ} 3^{\mathrm{TM}} \mathrm{m}^{\prime} \\
\text { Streptococcus. rattus } \mathrm{JH} 145\end{array}$ & $1 \times 10^{8} \mathrm{CFU}$ & 1 year & $\begin{array}{l}\text { Reduced early childhood } \\
\text { caries development }\end{array}$ & Human & 54 & [86] \\
\hline Plaque and carries & Lactobacillus brevis CD2 & NA & 6 weeks & $\begin{array}{l}\text { Beneficial effects on } \\
\text { variables associated } \\
\text { with oral health }\end{array}$ & Human & 91 & [87] \\
\hline Plaque and carries & $\begin{array}{l}\text { Bifidobacterium animalis subsp. } \\
\text { lactis BB-12 }\end{array}$ & $1 \times 10^{10} \mathrm{CFU}$ & 2 years & No significant effects & Human & 32 & [88] \\
\hline
\end{tabular}


Table 1 Selected probiotic preparations that have been investigated to treat various diseases (Continued)

\begin{tabular}{|c|c|c|c|c|c|c|c|}
\hline $\begin{array}{l}\text { Physiology or pathological } \\
\text { condition }\end{array}$ & Probiotic agent & $\begin{array}{l}\text { Probiotic } \\
\text { concentration }\end{array}$ & $\begin{array}{l}\text { Duration } \\
\text { of study }\end{array}$ & Effect (s) & Model & $\begin{array}{l}\text { Sample } \\
\text { (n) }\end{array}$ & $\overline{\text { Ref }}$ \\
\hline Plaque and carries & $\begin{array}{l}\text { Bifidobacterium animalis subsp. } \\
\text { lactis DN-173010 }\end{array}$ & $\geq 10^{8} \mathrm{CFU}$ & 4 weeks & $\begin{array}{l}\text { Effect on plaque } \\
\text { accumulation and } \\
\text { gingival inflammatory } \\
\text { parameters }\end{array}$ & Human & 26 & [89] \\
\hline Oral wounds & $\begin{array}{l}\text { A mixture of two probiotic strains, } \\
\text { Lactobacilli reuteri DSM } 17938 \text { and } \\
\text { ATCC PTA } 5289\end{array}$ & $2 \times 10^{8} \mathrm{CFU} / \mathrm{mL}$ & 1 week & No significant effects & Human & & [90] \\
\hline oral lichen planus (OLP) & $\begin{array}{l}\text { Lactobacilli reuteri (DSM } 17938 \text { and } \\
\text { ATCC PTA 5289) }\end{array}$ & NA & 16 weeks & No significant effects & Human & 9 & [91] \\
\hline Periodontitis & $\begin{array}{l}\text { L. rhamnosus } \\
\text { SP1 }\end{array}$ & $2 \times 10^{7} \mathrm{CFU}$ & 3 month & $\begin{array}{l}\text { Clinical and } \\
\text { microbiological } \\
\text { improvements. }\end{array}$ & Human & 16 & [92] \\
\hline Periodontitis & Lactobacillus reuteri & $1 \times 10^{8} \mathrm{CFU}$ & 3 weeks & $\begin{array}{l}\text { Decreased } \\
\text { pro-inflammatory } \\
\text { cytokine response } \\
\text { and improved clinical } \\
\text { parameters }\end{array}$ & Human & 24 & [93] \\
\hline Periodontitis & Lactobacillus reuteri & $1 \times 10^{8} \mathrm{CFU}$ & 12 weeks & $\begin{array}{l}\text { Useful adjunct to } \\
\text { scaling and root planing } \\
\text { (SRP) in chronic } \\
\text { periodontitis. }\end{array}$ & Human & 15 & [94] \\
\hline chronic periodontitis (CP) & Lactobacillus Reuteri & NA & 3 weeks & $\begin{array}{l}\text { Reduced inflammatory } \\
\text { markers }\end{array}$ & Human & 15 & [95] \\
\hline Periodontitis & L. rhamnosus SP1 & $2 \times 10^{7} \mathrm{CFU}$ & 3 months & Clinical improvement & Human & 12 & [96] \\
\hline Gingivitis & Bifidobacterium animalis & $\geq 10^{8} \mathrm{CFU}$ & 4 weeks & $\begin{array}{l}\text { Effects on plaque } \\
\text { accumulation and } \\
\text { gingival inflammation }\end{array}$ & Human & 26 & [89] \\
\hline Gingivitis & $\begin{array}{l}\text { Lactobacillus rhamnosus PB01, } \\
\text { DSM } 14869 \text { and Lactobacillus } \\
\text { curvatus EB10, DSM } 32307\end{array}$ & $\leq 10^{8} \mathrm{CFU} /$ tablet & 4 weeks & $\begin{array}{l}\text { Enhanced gingival } \\
\text { health }\end{array}$ & Human & 23 & [97] \\
\hline Gingivitis & $\begin{array}{l}\text { Bacillus subtilis, } \\
\text { Bacillus megaterium and Bacillus } \\
\text { pumulus as a toothpaste }\end{array}$ & $5 \times 10^{7} \mathrm{CFU}$ & 8 weeks & No significant effects & Human & 20 & [98] \\
\hline Gingivitis & $\begin{array}{l}\text { Lactobacillus plantarum, } \\
\text { Lactobacillus brevis and } \\
\text { Pediococcus acidilactici }\end{array}$ & NA & 6 weeks & $\begin{array}{l}\text { Significant changes in } \\
\text { mean gingival index }\end{array}$ & Human & 29 & [99] \\
\hline $\begin{array}{l}\text { Pregnancy } \\
\text { Gingivitis }\end{array}$ & Lactobacillus reuteri DSM 17938 & $\geq 10^{8} \mathrm{CFU}$ & 7 weeks & $\begin{array}{l}\text { Useful adjunct in the } \\
\text { control of pregnancy } \\
\text { gingivitis }\end{array}$ & Human & 24 & [100] \\
\hline Halitosis & Lactobacillus salivarius WB21 & $2 \times 10^{9} \mathrm{CFU}$ & 4 weeks & Improved halitosis & Human & 20 & [101] \\
\hline Halitosis & Lactobacillus brevis CD2 & NA & 2 weeks & No significant effects & Human & 10 & [102] \\
\hline Candida infection & Lactobacillus reuteri & $1 \times 10^{8} \mathrm{CFU}$ & 1 month & $\begin{array}{l}\text { Decreased incidence of } \\
\text { sepsis in addition to } \\
\text { improving symptoms } \\
\text { and feeding }\end{array}$ & Human & 150 & [103] \\
\hline Candida infection & $\begin{array}{l}\text { Lactobacillus fermentum LF10 } \\
\text { and L. acidophilus LA02 }\end{array}$ & $\geq 4 \times 10^{8} \mathrm{CFU}$ & 11 weeks & - & Human & 57 & [104] \\
\hline Candida infection & $\begin{array}{l}\text { Lactobacillus acidophilus, L. } \\
\text { rhamnosus, Streptococcus } \\
\text { thermophilus, and L. delbrueckii } \\
\text { subsp. bulgaricus }\end{array}$ & NA & & Prevented relapse & Human & 201 & [105] \\
\hline
\end{tabular}

seen after probiotic use. Probiotics reduced the level of the patient anxiety on the Hamilton Anxiety Scale (HAMA) from 19.8 to 10.2 . Consequently, clinical anxiety and biochemical features of stress were decreased by probiotics administration in the participants assigned for laryngectomy [116]. In another study carried out on patients with gastric cancer, the results showed that the combination of dietary fiber and probiotics was effective in treating post-operative diarrhea. The study included 120 patients suffering from GC. Patients were assigned to one of 3 groups as follows: (1) Fiber-enriched nutrition formula (FE group, $n=40$ ), (2) Fiber-free nutrition formula (FF group, $\mathrm{n}=40$ ), and (3) Fiber and probioticenriched nutrition formula, a combination of live bifidobacterium and lactobacillus in tablets , (FEP group, $\mathrm{n}=$ 40). Then, each patient received enteral nutrition (EN) 


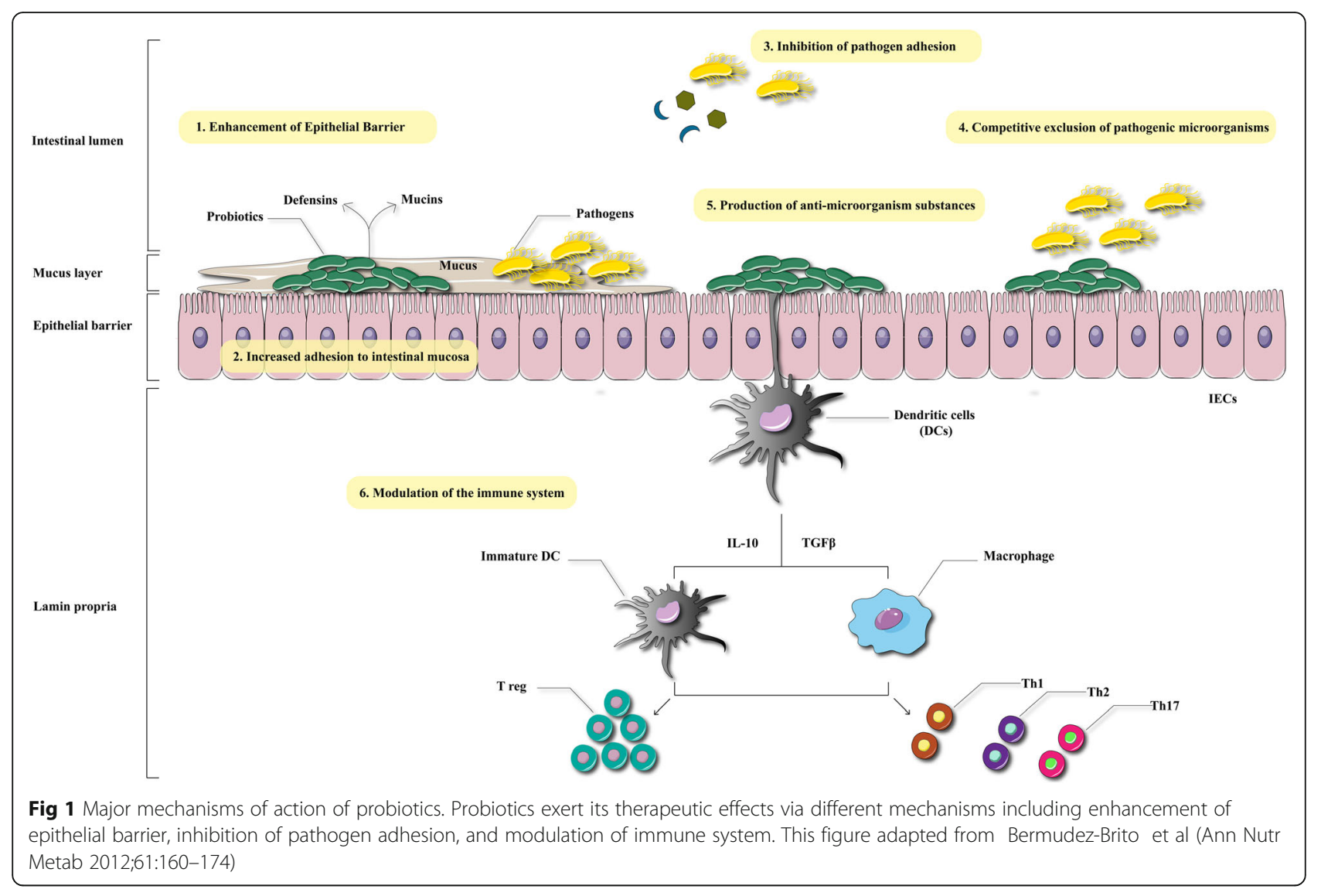

formulae for seven successive days after the surgical operation [117]. Earlier investigations had shown that addition of the fiber or probiotics may preserve the intestinal microecology, and diminish diarrhea related to EN [118]. Dietary fiber is a kind of carbohydrate polymer, which cannot be digested by humans. Some researchers have shown that the effects of combined probiotics and fiber on the treatment of diarrhea were indecisive [119-121]. According to the present RCT investigation, the combination of probiotics and fiber may reduce diarrhea, augment intestinal motility, and diminish intestinal dysfunction in the post-operative GC patients receiving EN. Additionally, probiotics may shorten the length of hospital stay (LOHS) as part of enhanced recovery after surgery (ERAS) protocols. Therefore, the combination of fiber and probiotics when beginning EN, may avoid diarrhea related to EN, improving comfort, and enhancing recovery after surgical operation [117].

Ventilator-associated pneumonia (VAP) is often caused by aspiration of pathogenic bacteria from the oropharynx. Oral decontamination by using antiseptics, such as antibiotics or chlorhexidine (CHX), can be used as prophylaxis. Klarin et al. examined the probiotic effect of bacteria Lactobacillus plantarum 299 (Lp299) as CHX in reducing the pathogenic bacteria in the oropharynx.
Fifty tracheally intubated, mechanically ventilated, critically ill patients critically ill patients administrated to either oral cleansing by $0.1 \%$ CHX solution or to the same washing procedure and oral using of an emulsion of Lp299. Oropharynx samples showed that pathogenic bacteria that were not present at inclusion were detected in the patients treated with Lp299 was less than those in control group [122].

Inflammatory bowel disease (IBD) consists of two disorders, Crohn's disease and ulcerative colitis [123]. In the pathogenesis of IBD, it is thought that pathogenic or resident luminal bacteria continuously activate the mucosal and systemic immune systems, and ultimately cause an inflammatory cascade [124]. IBD is a chronic immunological disease that is related to lack of dietary fiber, saturated fatty acids, poor sleep, and low levels of vitamin D in the body [123]. For medical therapy, drugs such as immunomodulators and 5-aminosalicylic acid (5-ASA) can be used [125]. Antibiotics and probiotics are also used to treat IBD [126]. So far, several studies have been performed to evaluate the efficacy of probiotics in IBD. In one study carried out by Shadnoush et al., supplementation with probiotics improved intestinal function in patients with IBD. A total of 305 participants were classified into 3 groups. Group A (IBD patients 
taking probiotic yogurt (contained Lactobacillus acidophilus La-5 and Bifidobacterium BB-12): $n=105$ ), group B (IBD patients taking a placebo: $n=105$ ), or control group (healthy persons taking probiotic yogurt: $n=95)$. Stool samples were obtained before and after eight weeks of intervention. Afterwards, the numbers of Bifidobacterium, Lactobacillus, and Bacteroides species in the stool samples were measured. It was found that the mean number of Bifidobacterium, Lactobacillus, and Bacteroides CFU in group A was increased compared to group B. Moreover, the mean number of all 3 bacteria was significantly different between groups $\mathrm{A}$ and $\mathrm{B}$ compared to healthy control group $\mathrm{C}$. The differences between the two groups were seen both at the base-line and the completion of the study. It has been found that consuming probiotic yogurt by IBD patients can contribute to the improved intestinal function via enhancing the numbers of the beneficial bacteria in the gut. Nonetheless, it is still necessary to do more studies to confirm this concept [40]. In one study that used a Lactobacillus reuteri rectal infusion in children with chronic ulcerative colitis (UC), mucosal inflammation and the expression of some pro-inflammatory cytokines was decreased. Oliva et al. investigated the effects of a Lactobacillus (L) reuteri ATCC 55730 enema on children with active distal UC, and measured inflammation and cytokine expression in the rectal mucosa. In a prospective, randomized, placebo-controlled trial, in addition to taking oral mesalazine, the patients $(n=40)$ received an enema solution containing $10^{10} \mathrm{CFU}$ of $L$. reuteri or placebo for eight weeks. The Mayo score (endoscopic and clinical characteristics) was considerably reduced in the L. reuteri group in comparison to the placebo. Moreover, histological scores showed a considerable decline in the L. reuteri group. In addition, at the post-trial assessment of the level of mucosal cytokine expression, the antiinflammatory IL-10 was significantly increased, while the pro-inflammatory TNF $\alpha$, IL- 8 and IL- $1 \beta$ were reduced in the L. reuteri group [127].

Kekkonen eta l. investigated production of cytokine in human peripheral blood mononuclear cells (PBMC) in response to stimulation with probiotic bacteria including Streptococcus thermophilus THS, Lactobacillus rhamnosus GG (ATCC 53103), Lactobacillus rhamnosus Lc705 (DSM 7061), Lactobacillus helveticus 1129, Lactobacillus helveticus Lb 161, Bifidobacterium longum 1/10, Bifidobacterium animalis ssp. lactis $\mathrm{Bb} 12$, Bifidobacterium breve $\mathrm{Bb} 99$ (DSM 13692), Lactococcus lactis ssp. cremoris ARH74 (DSM 18891), Leuconostoc mesenteroides ssp. cremoris PIA2 (DSM 18892) and Propionibacterium freudenreichii ssp. shermanii JS (DSM 7067). All of examined bacteria could induce TNF- $\alpha$ production. Streptococcus and Leuconostoc induced Th1 type cytokines IL-12 and IFN- $\gamma$ more than other. All
Propionibacterium and Bifidobacterium strains induced higher IL-10 production. They showed that Leuconostoc mesenteroides ssp. cremoris and Streptococcus thermophilus are more potent inducers of Th1 type cytokines IL-12 and IFN- $\gamma$ than the probiotic Lactobacillus strains [128].

Atopic dermatitis (AD) is an inflammatory skin disease can be due to the imbalance between Tcell-related immune responses. Sheikhi et al. investigated the effects of lactobacillus Bulgaricus in the yogurt culture on the secretion of Th1/Th2/Treg type cytokines by PBMCsin 20 children with AD. Results showed that L. Delbrueckii subsp. Bulgaricus significantly up-regulated the secretion of IL-10, IL-12 and IFN- $\gamma$, while secretion of IL-4 was decreased by PBMCs compared to control [129].

Some studies have suggested that arthralgia is a common extra-intestinal manifestation of IBD. It is possible that disturbing the immune profile within the gut plays a role in the pathogenesis of arthralgia. A study by Karimi showed that administration of probiotics (VSL\#3) could improve pouchitis in IBD patients. The safety and efficacy of VSL\#3 administration for 2 weeks in patients with quiescent IBD also suffering from arthralgia, was assessed in an open-label trial. The pre-treatment and post-treatment intensity of joint pain was measured using a visual analog scale and the Ritchie Articular Index. Moreover the Truelove-Witts and the HarveyBradshaw scores were used to assess severity of IBD symptoms. 16 of 29 patients completed the trial. 10 of these 16 patients showed a remarkable improvement in joint pain using the Ritchie Articular Index. No patients suffered a relapse of intestinal disease while on probiotics. The above results indicated that the probiotic supplement VSL\#3 could be a good therapeutic option for arthralgia inpatients suffering from IBD. Since probiotics can also serve as an IBD treatment, patients suffering from comcomitant arthralgia could take advantage of a dual treatment modality [130]. Another study carried out in laboratory dogs suggested that the antiinflammatory effects of probiotic administration could be due to reduced mucosal immune cell infiltration, accompanied by increased levels of putrescine (PUT), ornithine decarboxylase (ODC) and diamino-oxidase (DAO), which play an anti-inflammatory role [131].

Irritable bowel syndrome (IBS) is a common chronic disease of the GIT with an incidence of $3-20 \%$ in the US $[132,133]$. The exact mechanisms of IBS pathogenesis are still not fully understood, but immunological disturbances and low levels of inflammation contribute to the symptoms of the disease [134]. IBS is a complex of different symptoms, such as abdominal pain, diarrhea, constipation, and general bodily weakness [132]. The main treatments are drug therapy with anti-spasmodic and anti-diarrheal drugs, fiber-rich diet for constipation, 
and supportive treatment with low dose antidepressants [132]. In addition to these treatments, probiotics can also be used to treat IBS; Nevertheless the role of probiotic microorganisms in the treatment of IBS has not yet been fully confirmed [135]. Several studies have shown the reduction of IBS symptoms by probiotic administration; however, there is still not enough evidence about their impact on psychiatric comorbidity. For example, Pinto-Sanchez et al. carried out a prospective study to evaluate the effects of Bifidobacterium longum NCC3001 (BL) on depression and anxiety symptoms in patients suffering from IBS. The researchers randomly selected 44 IBS patients suffering from diarrhea for the trial. The patients took either BL $(n=22)$ or placebo $(n=$ 22) for 6 weeks. Afterwards, the levels of depression and anxiety, IBS symptoms, quality of life (QOL), and somatization were measured at weeks 0,6 , and 10 . This study demonstrated a reduction in depression by probiotic BL; however, they observed no reduction in the anxiety scores. Moreover, the probiotic BL increased QOL in IBS patients. They found a correlation between the psychological improvements and changes in the brain activation pattern, indicating a reduction in limbic reactivity by probiotics [49]. Mezzasalma et al. investigated the efficacy of a supplementary regimen containing multi-species probiotics to alleviate patient IBS symptoms, such as constipation (IBS-C), and also measured their gut microbiota. They conducted their study in 150 IBS-C participants who received orally administered probiotic mixtures $F \_1$ or F_2 or else placebo $F \_3$ for 60 days. The results showed that the improvement in symptoms was greater in the probiotic group in comparison with the placebo group. The symptoms also remained in remission during the follow-up period. Moreover, fecal analyses showed that the probiotics enhanced fecal bacterial DNA in participants who received F_1 and F_2, but not with F_3. A similar level continued during the follow-up course [136]. In another study, Choi et al. explored the effectiveness of a combined treatment with mosapride and probiotics in IBS patients without diarrhea. They randomly assigned 285 IBS patients to receive over 4 weeks, a combined treatment with probiotics (Streptococcus faecium \& Bacillus subtilis) plus mosapride at 4 different dosages (groups 1-4), or a placebo. The proportion gaining AR at the fourth week was greater in all treatment groups in comparison with the placebo group. Moreover, the proportion of the patients who improved on the SGA was also greater in the treatment groups compared to the placebo group. In addition, abdominal discomfort and pain scores in treatment group 4 showed the best improvement in comparison to the placebo group. In patients suffering from constipation-predominant IBS, greater improvement was observed in stool frequency and consistency in the treatment groups 4 and 1 as compared to the placebo group [137].

Celiac disease (CD) is a chronic immune-mediated disease caused by the consumption of foods containing gluten, especially wheat, and is most often seen in genetically-predisposed individuals [138]. The part of the intestines involved in $\mathrm{CD}$ is the proximal section of the small intestine [139]. The prevalence of celiac disease is different worldwide, but its incidence has increased in the last few decades [140]. Currently, the only effective treatment for patients with $\mathrm{CD}$ is a gluten-free diet (GFD) [141]. Of course, the effectiveness of this treatment depends on the strict avoidance of gluten, which may sometimes be difficult [141]. In patients with celiac disease, as compared to healthy people, the beneficial gut microbes have been shown to be decreased, and the potentially pathogenic microbes are increased [142]. This change in the microbiome increases the inflammatory response in the intestine and worsens celiac disease [142]. Considering the role of probiotics in modulating microbial populations, probiotics could be used to reduce inflammatory response and to improve the symptoms of celiac disease. In a study evaluating the effects of Bifidobacterium infantis Natren Life Start (NLS) strain super strain in patients with $C D$, it was concluded that this strain could relieve the symptoms of untreated individuals. 22 patients who were positive for two different CD-specific tests were enrolled in this study. The patients were randomly assigned to take two capsules before meals for three weeks, containing either placebo or Bifidobacterium infantis super strain (Lifestart 2). It was found that $B$. infantis alleviated the symptoms in the untreated $C D$ patients. Moreover, probiotics produced a number of immunologic alterations, but the abnormal intestinal permeability was not affected [60]. Another study conducted by Olivares et al. used Bifidobacterium longum CECT 7347 in children with newly diagnosed $\mathrm{CD}$, showed that this probiotic could improve the QOL in subjects. They assessed the effects of oral administration of the B. longum CECT 7347 in 33 children who were diagnosed with $\mathrm{CD}$, after they had been on a gluten-free diet (GFD) for a three-month period. It was concluded that oral administration of B. longum CECT 7347 in combination with a GFD decreased the potentially pro-inflammatory bacteria in the gut ( $B$. fragilis group) which have been associated with $C D$ in earlier studies, as well as fecal sIgA (soluble immunoglobulin A). In addition, B. longum CECT 7347 decreased activated T-lymphocytes and inflammatory markers (TNFa), possibly showing improved immune homeostasis in $\mathrm{CD}$ patients [59]. Another study that investigated the effects of a probiotic consisting of two strains Bifidobacterium breve BRO3 and B. breve B632 in children with $\mathrm{CD}$ combined with a GFD, showed that the TNF- $\alpha$ 
inflammatory cytokine was decreased in these children after the intervention [143]. In vitro investigations also showed that several strains of Bifidobacteria could lower levels of pro-inflammatory cytokines (TNF- $\alpha$, IFN- $\gamma$, \& IL-2) and increase levels of the anti-inflammatory cytokine (IL-10). Bifidobacteria may be able to reverse the pro-inflammatory milieu caused by the microbiota of patients with CD [144-146]. Moreover, many researchers have shown that $B$. breve strains can exert immunomodulatory effects both in vitro and in vivo $[147,148]$. It has been established that these probiotics bacteria possess the Qualified Presumption of Safety status [149]. Two recent studies have shown that intestinal inflammation can be prevented by $B$. breve strains via induction of a population of T-regulatory $1(\operatorname{Tr} 1)$ cells that secrete IL-10 [150, 151]. It is possible that gliadin-specific $\operatorname{Tr} 1$ cell clones could suppress the proliferation of pathogenic T-cells in CD patients [152]. Autoimmune-type dysfunction in known to be increased in CD patients [153]. Supplementation with $B$. breve probiotics plus a GFD can ameliorate the pro-inflammatory environment in the $\mathrm{CD}$ gut, and thus reduce the recurrence of the disease. In another study, Klemenak et al. determined the effects of a combined treatment with B. breve strains $\mathrm{B} 632$ and BR03 plus a GFD on the immunological function of CD children by measuring serum levels of TNF-a and IL-10. They randomly assigned 49 CD children on a GFD into treatment and placebo groups, plus 18 healthy children in a control group. The first group (24 CD children) took $B$. breve strains $\mathrm{BR} 03$ and $\mathrm{B} 632\left(2 \times 10^{9}\right.$ colonyforming units) per day, while the second group ( $25 \mathrm{CD}$ children) took a placebo for three months. The results showed a significant reduction in the level of TNF- $\alpha$ in the first group after the administration of $B$. breve for three months. Follow-up three months after the end of the study showed that level of TNF- $\alpha$ increased once again. The levels of IL-10 were below the detection level in each group. They concluded that probiotic B. breve strains could decrease the proinflammatory cytokine TNF-a in CD children on a GFD [61]. Quagliariello et al. also found that a supplement of Bifidobacterium breve (B632 and BR03) in CD children treated with GFD could increase the amount of beneficial microbial compounds in the gut [154].

In a study the response of intestinal epithelial cells to Enterococcus faecium NCIMB 10415 (E. faecium) and two pathogenic E. coli strains was examined, with focus on the probiotic modulation of the response to the pathogenic challenge. Intestinal cells (IPEC-J2 and Caco2) were incubated without bacteria (control), with E. faecium, with enteropathogenic (EPEC) or enterotoxigenic E. coli (ETEC) each alone or in combination with E. faecium. Results showed that the ETEC strain decreased transepithelial resistance (TER) and increased IL-8
mRNA and protein expression in both cell lines compared with control cells, an effect that could be prevented by pre- and coincubation with E. faecium. Similar effects were observed for the increased expression of heat shock protein 70 in Caco- 2 cells. When the cells were challenged by the EPEC strain, no such pattern of changes could be observed. The reduced decrease in TER and the reduction of the proinflammatory and stress response of enterocytes following pathogenic challenge indicate the protective effect of the probiotic [155].

Rheumatoid arthritis (RA) is the most common type of inflammatory arthritis, and is a main cause of disability [156]. Inflammatory cytokines play an important role in the pathogenesis of RA. An imbalance between proinflammatory and anti-inflammatory cytokines causes induction of autoimmunity and chronic inflammation resulting in joint damage [157]. Epidemiological studies have estimated a $0.5-1 \%$ prevalence worldwide, and an annual average incidence of $0.02-0.05 \%$ in the Northern European and North American regions [158]. There are several drugs given to patients with RA, one of which is methotrexate (MTX) [159]. However all of these drugs have side effects that can adversely affect the QOL of RA patients. For example, MTX commonly causes GI symptoms and elevation of hepatic enzymes, while severe hemocytopenia and MTX pneumonitis occur less frequently [160]. Given the role that probiotics play in down-regulating inflammatory cytokines [161], they could be substituted for drugs in the treatment of RA. In a study by Mandel, supplementation with Bacillus coagulans GBI-30 was shown to be effective in patients with RA [162]. A probiotic mixture of three strains of Lactobacillus acidophilus, Lactobacillus casei and Bifidobacterium bifidum was given for 8 weeks to patients with RA. Probiotics showed positive effects on serum insulin levels, assessment of B cell function (HOMA-B), and serum high-sensitivity C-reactive protein (hs-CRP) concentrations in a study by Zamani et al [42]. Another study was conducted to investigate the effects of Lactobacillus casei 01 in RA patients. At the end of the intervention it was found that this strain could reduce the symptoms of this disease. The researchers randomly assigned women with established RA to receive either a placebo or one capsule containing $10^{8}$ colony-forming units (CFU) of L. casei 01 for eight weeks. Serum levels of cytokines IL-1 $\beta$, IL-10, IL-6, TNF- $\alpha$ and IL-12 were measured. They concluded that $L$. casei 01 could decrease the serum level of hs-CRP, improve swollen joints and tenderness, and increase the global health score and disease activity score-28 $(\mathrm{P}<0.05)$. They showed a significant difference between both groups for IL-12, IL-10, and TNF- $\alpha$ levels over the study $(\mathrm{P}<0.05)$, in favor of the probiotic group. There were no adverse effects in the intervention group. They concluded that probiotics 


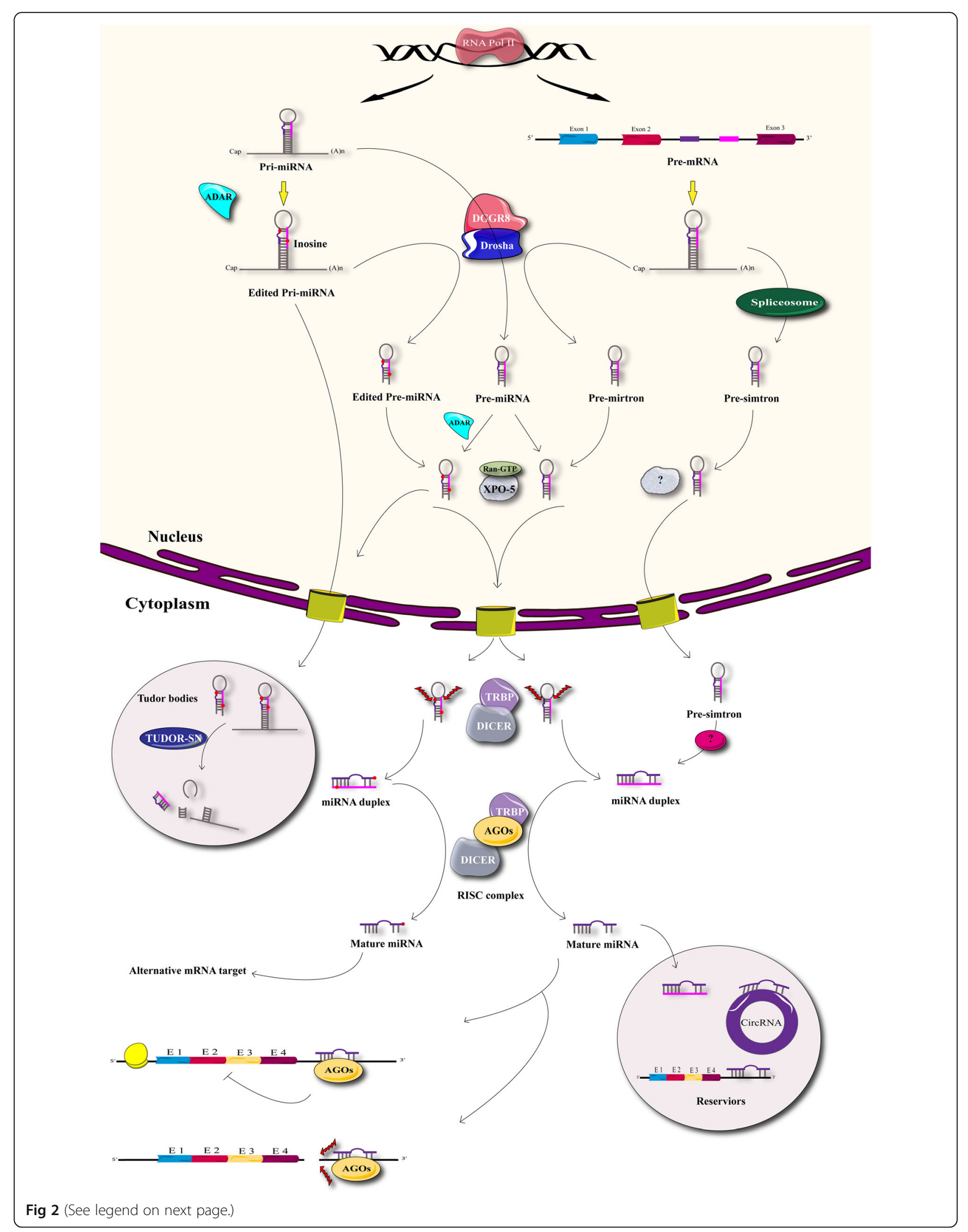


(See figure on previous page.)

Fig 2 Biogenesis of miRNA. Starts in the nucleus when miRNA genes are transcribed by RNA polymerase II as large polyadenylated RNA

molecules named primary miRNAs (pri-miRNAs). Pri-miRNAs are processed in the nucleus by RNase III Drosha and microprocessor complex subunit DGCR8. As a result, pri-miRNAs are cleaved into smaller double-stranded RNA (dsRNA) molecules known as pre-miRNAs and then are exported to the cytoplasm by exportin 5 (XPO5). Pre-miRNAs in the cytoplasm are cleaved and despoiled of their loops by the RNase III enzyme Dicer in association with TRBP into mature miRNAs consisting of a $~ 22$-nucleotide duplex. The last processing step is carried out by a ribonucleoprotein complex known as RNA-induced silencing complex (RISC), which can unwind both strands. Although either strand of the miRNA duplex could potentially act as a mature miRNA, usually only one of the strands is incorporated into the RISC complex to induce mRNA silencing. RISC-loading complex (RLC), consisted of Dicermm, Argonaute 2 (Ago2), and TRBP. Once loaded, the RISC complex finds a complementary strand, activates RNase and cleaves the RNA

could be a useful supplement for patients with RA, to alleviate symptoms and reduce inflammatory cytokines [163]. In a study by Hatakka et al. supplementation with Lactobacillus rhamnosus GG (LGG) reduced the severity of RA. However, probiotic therapy with Lactobacillus GG showed no effects on RA severity. Therefore, it is necessary to do more research into probiotic bacteria for RA patients [164].

\section{Modulation of microRNA by probiotics}

MicroRNAs (miRNAs) are short non-coding RNAs comprising 20 to 24 nucleotide bases, which play important roles in all the biological and physiological pathways in multicellular organisms [165]. Figure 2 shows the scheme of miRNA biogenesis. Dysregulation of microRNAs plays an important role in the pathogenesis of many different diseases [165]. These diseases include, central nervous system disorders [166], autoimmune diseases [167], cancers [168] and many other common diseases worldwide. Some treatments that are used to cure these diseases act by influencing gene expression and affecting miRNA regulation [169-171].

Probiotics are among other biological factors that have recently been discussed with regard to whether they have any effects on miRNAs. Many laboratory studies have so far been done to investigate the effects of probiotics on miRNAs (Table 2).

In one study by Heydari et al. supplementation with Lactobacillus acidophilus and Bifidobacterium bifidum probiotics in a mouse model of azoxymethane (AOM)induced colon cancer was investigated. The results showed that the expression levels of miR-135b, miR-155, and KRAS (one of the target genes of these miRNAs) increased after azoxymethane cancer induction, and administration of a probiotic preparation containing Lactobacillus acidophilus and Bifidobacterium bifidum decreased the above-mentioned factors. Conversely, cancer induction with azoxymethane reduced the expression of miR-26b, miR-18a, APC, PU.1, and PTEN in mice, and probiotic supplementation increased them again. It seems that Lactobacillus acidophilus and Bifidobacterium bifidum though increasing the expression of the tumor suppressor miRNAs and their target genes and decreasing the oncogenes can improve colon cancer treatment [173].

Enterococcus faecium NCIMB 10415 is a probiotic species that has been shown to affect the intestinal microbial flora, and improve the immune system response in numerous human and animal studies $[188,189]$. In one in vitro study using next-generation sequencing, Kreuzer-Redmer and colleagues analyzed the differential expression of the miRNAs and potential target genes in the ileal and jejunal lymphatic tissue isolated from piglets which had been fed with E. faecium NCIMB 10415 versus control animals. They found that feeding $E$. faecium affected the expression of miR-423-5p as well as regulating its target gene IGLC. Therefore, E. faecium benefits the immune cells in the small intestine probably by affecting the expression of miR-423-5p [174].

Escherichia coli Nissle $1917(E c N)$ is a non-pathogenic Gram-negative bacterium of the Enterobacteriaceae family, which when used as a probiotic, has beneficial effects on human health [190]. In one in vitro study, E. coli (EPEC) pathogenic strain E2348/69 and E. coli Nissle $1917(E c N)$ were tested in human T84 and THP-1 cells to compare the effects of the two strains on cytokine and miRNA expression. EcN increased the expression of CXCL1 and IL-8 in human T84 epithelial cells infected from the basolateral side. miR-146a is a molecular adaptor in the Toll-like receptor (TLR)/NF- $\mathrm{B}$ signaling pathway. In this study, miR-146a was increased in T84 and THP-1 cells treated with EPEC, but this increase was less pronounced when these cells were incubated with EcN. Two miR-146a target genes were also identified, including IRAK1 and TRAF6. So, the probiotic EcN induced the expression of miR-146a in epithelial and immune cells, though this induction was reduced by incubation with pathogenic strain EcN [177].

miR-122 is the most frequent miRNA found in the liver, and plays an important role in liver biology and the pathogenesis of liver diseasess [191]. MiR-122 can down-regulate the proliferation and transactivation of hepatic stellate cells (HSCs) which play a role in liver fibrosis [192]. It is well known that alcoholic liver disease (ALD) causes a great burden of morbidity and death. In fact, persistent use of alcohol affects the homeostasis of the intestinal microflora, increases endotoxemia, disrupts 


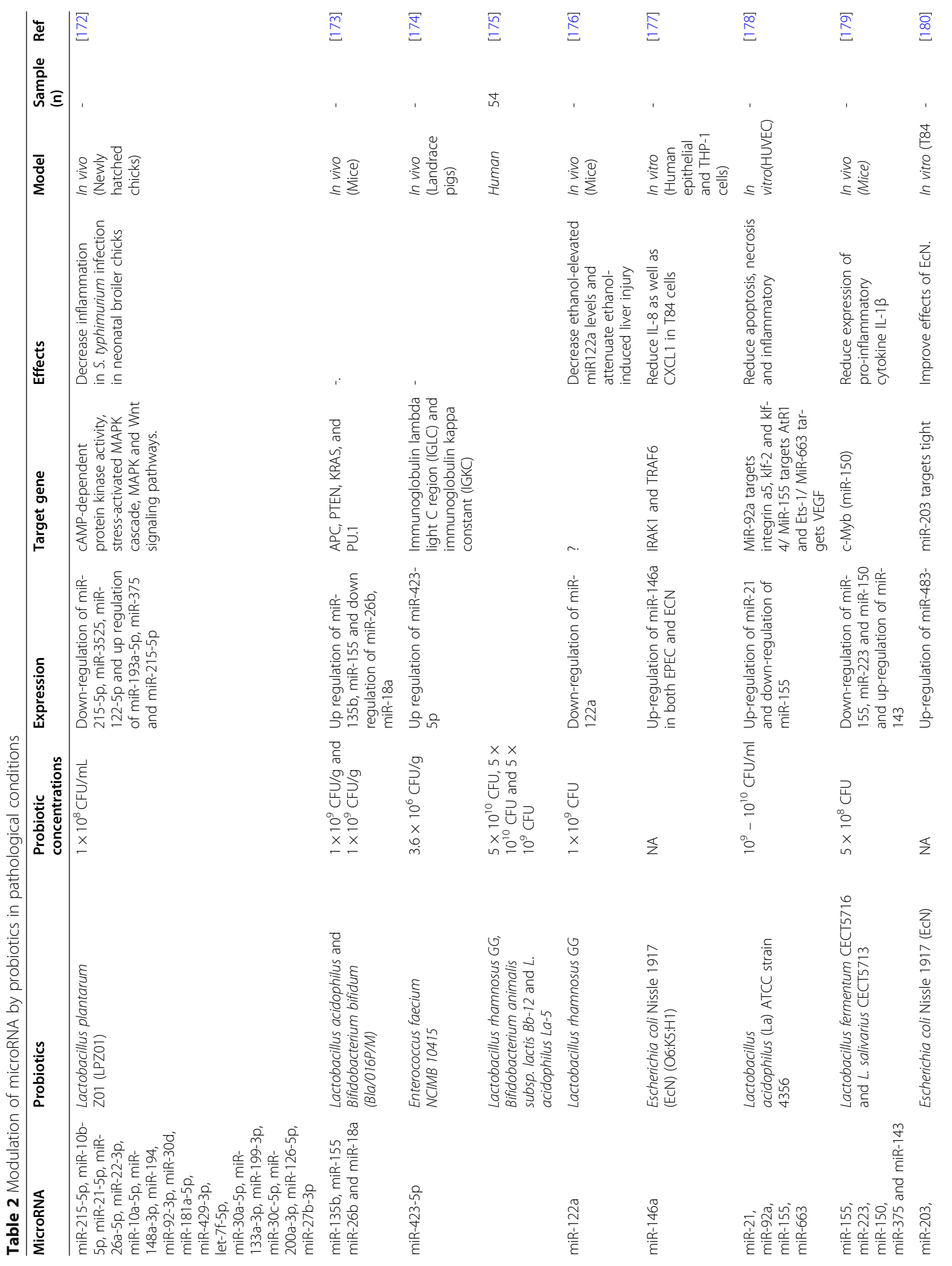




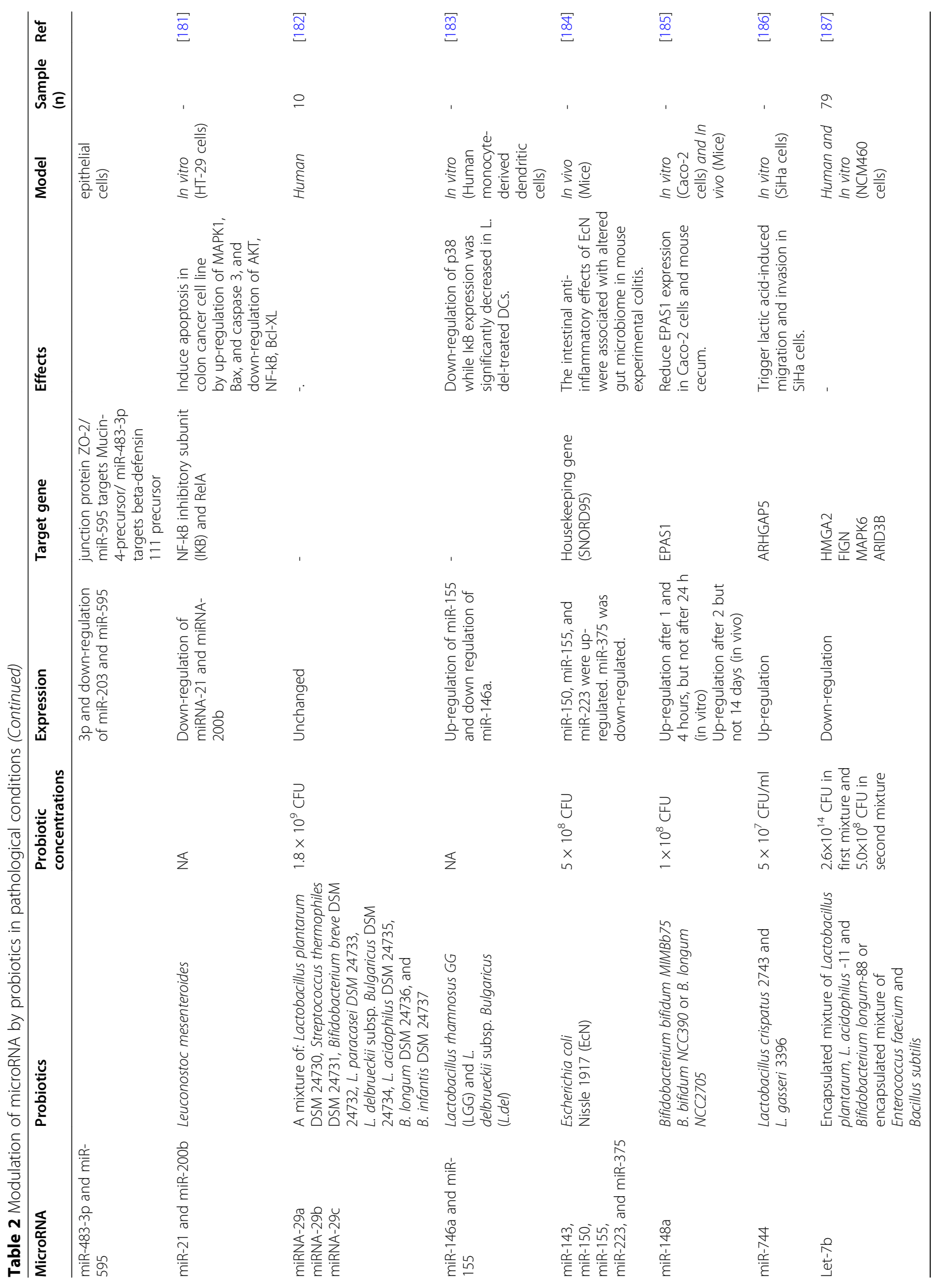


the intestinal cell tight junction barrier, and causes liver steatosis or steatohepatitis. It was shown that a bacteriafree LGG culture supernatant (LGGs) and probiotic Lactobacillus rhamnosus GG (LGG) both promoted intestinal epithelial integrity and protected intestinal barrier function in ALD. Nonetheless, there is insufficient information on the mechanism of action of LGGs for increasing intestinal tight junction proteins. Another study conducted by Zhao et al. found that chronic ethanol exposure could increase the expression of the intestinal miR122a and decrease the expression of occludin, causing increased intestinal permeability. Supplementation with LGGs decreased the levels of miR122a caused by ethanol administration, and lessened ethanol-induced liver damage in mice. Over-expression of miR122a in a Caco-2 cell mono-layer caused a remarkable reduction in the level of occludin protein, similar to ethanol exposure. On the contrary, inhibiting miR122a increased the expression of occludin. It was suggested that a LGG supplementary regimen could affect intestinal integrity via inhibiting miR122a, thereby restoring levels occludin in the mice subjected to chronic ethanol intake [176].

Infection with high-risk human papillomavirus (HPV), and subsequent genomic integration leads to cervical cancer. Notably, E6 and E7 oncogenes are expressed leading to immortalizing the cells, and the effects on cell migration and invasion predispose to tumor metastasis [193]. Nonetheless, there is insufficient data on the fundamental mechanisms underlying this process, including the movement of the cervical cancer cells into the tumor micro-environment. In addition, lactic acid has been commonly viewed as an important constituent of the tumor microenvironment, as it is a by-product of glycolysis. In fact, researchers have suggested that the lactic acid content in primary malignant lesions could be a prognostic marker for the patient overall survival and risk of metastasis [194]. Based on some studies, there was a correlation between higher amounts of lactic acid and the risk of metastasis and poor prognosis in head and neck squamous cell carcinoma, rectal adenocarcinoma and cervical cancer [194, 195]. However, little attention has been paid to the biology of lactic acid in cervical cancer. For instance, Li et al. assessed the effects of lactic acid on the invasion and migration of the HPV16 positive SiHa cells. It was found that the addition of extra-cellular lactic acid reduced the expression of E7 and 16 HPV-16 E6 oncogenes, and increased the migration and invasion of $\mathrm{SiHa}$ cells by upregulating miRNA-744 levels. This research added further knowledge about the relationship between lactic acid, cell migration and invasion, and implicated the miR-774 in the mechanism [186].

In a study by Liu et al., a study population of 186 patients was recruited who underwent surgery for colorectal cancer. The intervention group $(n=93)$ received either an encapsulated mixture of Lactobacillus plantarum (CGMCC No.1258), L. acidophilus-11 and Bifidobacterium longum-88 or an encapsulated mixture of Enterococcus faecium and Bacillus subtilis, while the placebo group $(n=93)$ received maltodextrin capsules. The intervention group showed reduced levels of complications and infection, accompanied by increased serum and tissue levels of the miRNA let-7b. In this study, P38 MAPK was identified as a target gene for let$7 \mathrm{~b}$ using NCM460 cells. Therefore, it could be suggested that mixture of probiotics used in this study reduced the complications and infection after surgery for colorectal cancer probably through increasing the level of the miRNA let-7b [187].

The mir-148/mir-152 family is composed of three highly conserved mature miRNAs with similar sequences, structures and the same core region (i.e., UCAGUGCA). This family includes mir-148a, mir-148b and mir-152. The precursor mir-148/mir-152 has a stemloop structure which is cleaved by a series of enzymes in the nucleus and cytoplasm to form mir-148a, mir-148b and mir-152 sequences [196]. In one study, the miRNAs in Caco-2 cells and cecal tissue from mice were evaluated after treatment with Bifidobacterium bifidum MIMBb75, B. bifidum NCC390 or B. longum NCC2705 probiotics. After 1 and 4 hours miR-148a was increased in response to B. bifidum MIMBb75 in Caco-2 cells. In the animal study, Taibi et al. explored whether Bifidobacterium strains (including Bifidobacterium bifidum MIMBb75, B. bifidum NCC390 or B. longum NCC2705) could change the expression of the miR-148a and its target gene in the intestines. The expression of miR-148a and its respective validated target EPAS1 in Caco-2 cells and mouse cecum in response to B. bifidum NCC390, $B$. bifidum MIMBb75, and B. bifidum NCC2705 was evaluated. It was concluded that in vitro exposure to $B$. bifidum MIMBb75 (but not B. bifidum NCC390 or B. longum NCC2705) increased the expression of miR-148a after 1-4 hours $(\mathrm{p}<0.01)$ but not after 24 hours. Administration of B. bifidum MIMBb75 to C57BL/6J mice enhanced the expression of miR-148a in the cecum after 2 but not 14 days $(p<0.05)$. It was found that increased miR-148a expression was followed by reduced EPAS1 expression in the Caco- 2 cells and cecal tissue $(\mathrm{p}<0.05)$. Finally, it was shown that silencing miR-148a could reverse the $B$. bifidum MIMBb75-dependent downregulation of EPAS1 [185].

Another study used E. coli Nissle 1917 as a probiotic, and investigated the effects of this strain on the expression of inflammatory cytokines and miRNAs in mice with dextran sodium sulfate (DSS)-induced colitis. Probiotic treatment reduced the secretion of inflammatory cytokines and restored epithelial integrity. Probiotic 
treatment also restored to normal levels the various types of miRNAs involved in the inflammation process (miR-143, miR-150, miR-155, miR-223, and miR-375). They concluded that probiotics could modulate the expression of miRNAs in the colitis affected mice to ameliorate inflammation and restore gut homeostasis [184].

Toll like receptor 4 (TLR4) is an pathogen recognition receptor (PRR) expressed on many immune cells [197]. The TLR4 signaling pathway plays an important role in triggering the innate immune response in many inflammatory disorders [198]. P38 mitogenactivated protein kinases (MAPKs) are activated in response to many factors, such as inflammatory cytokines. There are four members of the p38MAPK family ( $\mathrm{p} 38 \alpha, \mathrm{p} 38 \beta, \mathrm{p} 38 \gamma$ and $\mathrm{p} 38 \delta)$. The p38MAPK signaling pathway plays a major role in the biosynthesis of inflammatory cytokines, and can be used as a target to treat various disorders of the immune system [199]. One in vitro study investigated the effects of probiotics on immune responses using Lactobacillus rhamnosus $G G$ (LGG) and L. delbrueckii subsp. Bulgaricus ( $L$. del) as probiotics added to human monocyte-derived dendritic cells (DCs). The use of $L G G$ reduced the expression of p38 MAP kinase during the intervention. Also, the expression of ІкB was significantly reduced in the $L$. del. group. The probiotic LGG could regulate immune system responses through increasing the level of miR-155 as well as reduction the expression of miR-146a which targets NFKB [183].

Leuconostoc species are lactic acid bacteria used as fermentation agents in numerous foods, and in the food and beverage industry. Leuconostoc spp. naturally produce chemical compounds that have inhibitory properties against other bacteria. The most important of these compounds are called bacteriocins (antibacterial peptides) [200]. One study performed by Vahed et al. investigated the anticancer effects of Leuconostoc mesenteroides in colon cancer cells (HT-29). Researchers isolated the $L$. mesenteroides strain from conventional dairy products. HT-29 cells were treated with the conditioned-medium of L. mesenteroides bacteria, and apoptosis was examined. This study showed that $L$. mesenteroides medium as a potential adjunctive treatment for cancer could promote apoptosis in the colon cancer cells via up-regulating Bax, MAPK1 and caspase 3, and down-regulating NF- $\mathrm{BB}, \mathrm{AKT}$, Bcl-XL, probably by reducing the expression of oncomiRNAs, including miR-200b and miR-21 (Fig. 3 )[181].

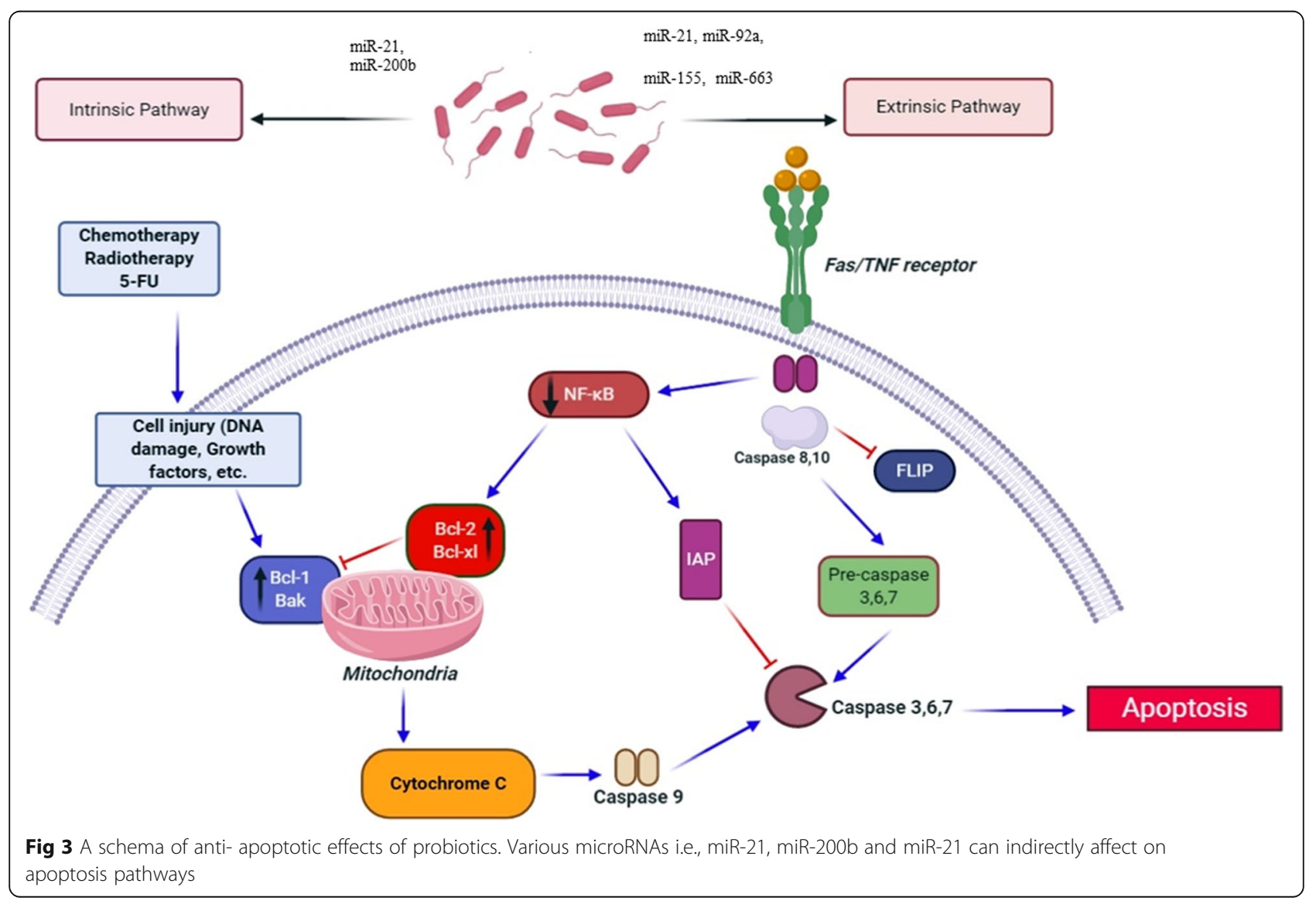




\section{Conclusions}

The investigation of the interaction between human health and the gut microbiota, is essential for understanding many diseases of the modern world. As the human diet has become steadily more processed, it is thought that the gut is no longer exposed to many bacteria as it has been for most of human evolution. Accumulating data suggests that the administration of probiotics, living microorganisms typical of the healthy human gut, could have a crucial role in the prevention and treatment of many pathological conditions. Probiotics may function through several signaling pathways and by regulating biochemical biomarkers, such as miRNAs. Therefore, evaluation of the possible relationship between probiotics and miRNAs is important to discover the underlying role of gut microbiota in human health. Regarding the concept of the application of probiotics in different foods, such as yoghurt, milk and cheese, and their use as supplements to the human diet, future investigations should focus on the role of miRNAs, and further animal studies and clinical trials will be required before clear guidelines can be laid down.

\footnotetext{
Abbreviations

5-ASA: 5-aminosalicylic acid; AD: Atopic dermatitis; AGE: Acute gastroenteritis; Ago2: Argonaute 2; ALD: Alcoholic liver disease; AOM: Azoxymethane; APC: Adenomatous polyposis coli; AR: Adequate relief; AST: Aspartate transaminase; B: Bifidobacterium; BCl-XL: B-cell lymphoma-extra large; BL: Bifidobacterium longum NCC3001; BL: Bifidobacterium longum; BMl: Body mass index; CD: Celiac disease; CFU: Colony-forming unit; CP: Chronic periodontitis; CRC: Colorectal cancer; CRF: Corticotropin-releasing factor; CXCL1: Chemokine (C-X-C motif) ligand 1; DAO: Diamino-oxidase; DC: Dendritic cells; dsRNA: Double-stranded RNA; DSS: Dextran sodium sulfate; E. faecium: Enterococcus faecium; ECN; ECN: Escherichia coli Nissle; EN: Enteral nutrition; EPAS1: Endothelial PAS domain-containing protein 1; EPEC: Escherichia coli; ERAS: Enhanced recovery after surgery; FE: Fiberenriched; FEP: Fiber- and probiotic-enriched; FF: Fiber-free; GC: Gastric cancer; GFD: Gluten-Free Diet; GIT: Gastrointestinal tract; HAMA: Hamilton Anxiety Scale; HOMA-B: Homeostatomy model assessment-B cell function; HPV: Human papillomaviruses; hs-CRP: High-sensitivity C -reactive protein; HSC: Hepatic stellate cells; IBD: Inflammatory bowel disease; IBS-C: IBS symptoms related to constipation; IBS: Irritable bowel syndrome; IFNY: Interferon gamma; IGKC: Immunoglobulin kappa constant; IGLC: Immunoglobulin Lambda Constant 1; IGLC: Immunoglobulin lambda light $C$ region; IL-1 $\beta$ : Interleukin-1 beta; IL: Interleukin; KRAS: Kirsten rat sarcoma viral oncogene; L: Lactobacillus; L.del: Lactobacillus delbrueckii; La: Lactobacillus acidophilus; LcS: Lactobacillus casei strain Shirota; LGG: Lactobacillus rhamnosus GG; LOHS: length of hospital stay; LP: Lactobacillus paracasei; LPR: Lactobacillus rhamnosus; LPZ01: Lactobacillus plantarum Z01; LR: Lactobacillus rhamnosus; MAPK: Mitogen-activated protein kinase; miRNAs: MicroRNAs; MTX: Methotrexate; MYB: Myeloblastosis; NEC: Necrotizing enterocolitis; NF-kB : Nuclear factor kappa-light-chain-enhancer of activated B cells; ODC: Ornithine decarboxylase; PCR: Polymerase chain reaction; Pri-miRNAs: Primary miRNAs; PRR: Pathogen recognition receptor; PTEN: Phosphatase and tensin homolog; PUT: Putrescine; RA: Rheumatoid arthritis; RCT: Randomized controlled trial; RISC: RNAinduced silencing complex; RLC: RISC-loading complex; SGA: Subjects' global assessment; SRP: Scaling and root planning; TLR: Toll-like receptor; TNFa: Tumor necrosis factor alpha; Tr1: T-regulatory 1; TRBP: Transactivation response element RNA-binding protein; UC: Ulcerative colon; UTI: Urinary tract infection; XPO5: Exportin 5
}

\section{Authors' contributions}

$\mathrm{HM}$ and $\mathrm{MRH}$ contributed in conception, design, statistical analysis and drafting of the manuscript. AD, HM, PG, AS, MM-T, SR, and HT contributed in data collection and manuscript drafting. All authors approved the final version for submission.

\section{Funding}

The present study was founded by a grant from the Vice Chancellor for Research, Kashan University of Medical Sciences, in Iran. MRH was supported by US NIH Grants R01Al050875 and R21Al121700.

\section{Availability of data and materials}

The primary data for this study is available from the authors on request.

\section{Ethics approval and consent to participate}

Not applicable.

\section{Consent for publication \\ Not applicable.}

\section{Competing interests}

$\mathrm{MRH}$ declares the following potential conflicts of interest. Scientific Advisory Boards: Transdermal Cap Inc, Cleveland, OH; BeWell Global Inc, Wan Chai, Hong Kong; Hologenix Inc. Santa Monica, CA; LumiTheralnc, Poulsbo, WA; Vielight, Toronto, Canada; Bright Photomedicine, Sao Paulo, Brazil; Quantum Dynamics LLC, Cambridge, MA; Global Photon Inc, Bee Cave, TX; Medical Coherence, Boston MA; NeuroThera, Newark DE; JOOW Inc, Minneapolis-St. Paul MN; AIRx Medical, Pleasanton CA; FIR Industries, Inc. Ramsey, NJ; UVLRx Therapeutics, Oldsmar, FL; Ultralux UV Inc, Lansing Ml; Illumiheal\&Petthera, Shoreline, WA; MB Lasertherapy, Houston, TX; ARRC LED, San Clemente, CA; Varuna Biomedical Corp. Incline Village, NV; Niraxx Light Therapeutics, Inc, Boston, MA. Consulting; Lexington Int, Boca Raton, FL; USHIO Corp, Japan; Merck KGaA, Darmstadt, Germany; Philips Electronics Nederland B.V. Eindhoven, Netherlands; Johnson \& Johnson Inc, Philadelphia, PA; SanofiAventis Deutschland GmbH, Frankfurt am Main, Germany. Stockholdings: Global Photon Inc, Bee Cave, TX; Mitonix, Newark, DE. The other authors declare no conflicts of interest.

\section{Author details \\ ${ }^{1}$ Student Research Committee, Kashan University of Medical Sciences, Kashan, Iran. ²Department of Veterinary Pathology, Faculty of Veterinary Medicine, University of Tehran, Tehran, Iran. ${ }^{3}$ Department of Genetics, Faculty of Biology,Sana Institute of Higher Education, Sari, Iran. ${ }^{4}$ Biotechnology Research Center, Pharmaceutical Technology Institute, Mashhad University of Medical Sciences, Mashhad, Iran. ${ }^{5}$ Neurogenic Inflammation Research Center, Mashhad University of Medical Sciences, Mashhad, Iran. ${ }^{6}$ Faculty of Medicine, Kashan University of Medical Sciences, Kashan, Iran. ${ }^{7}$ Student Research Committee, Mashhad University of Medical Sciences, Mashhad, Iran. ${ }^{8}$ Department of Medical Biotechnology, Faculty of Medicine, Mashhad University of Medical Sciences, Mashhad, Iran. ${ }^{9}$ Department of Animal Biotechnology, National Institute of Genetic Engineering and Biotechnology (NIGEB), Tehran, Iran. ${ }^{10}$ Wellman Center for Photomedicine, Massachusetts General Hospital, Harvard Medical School, 40 Blossom Street, Boston, MA 02114, USA. ${ }^{11}$ Research Center for Biochemistry and Nutrition in Metabolic Diseases, Institute for Basic Sciences, Kashan University of Medical Sciences, Kashan, Iran.}

Received: 14 June 2020 Accepted: 22 September 2020

Published online: 11 January 2021

References

1. Hooper LV, Littman DR, Macpherson AJ. Interactions between the microbiota and the immune system. Science. 2012;336(6086):1268-73.

2. Fábrega M-J, Rodríguez-Nogales A, Garrido-Mesa J, Algieri F, Badía J, Giménez R, Gálvez J, Baldomà L. Intestinal anti-inflammatory effects of outer membrane vesicles from Escherichia coli Nissle 1917 in DSS-experimental colitis in mice. Front Microbiol. 2017;8:1274.

3. Aragon F, Carino S, Perdigon G, de Moreno de LeBlanc A. Inhibition of growth and metastasis of breast cancer in mice by milk fermented with Lactobacillus casei CRL 431. J Immunother. 2015;38(5):185-96. 
4. So SS, Wan ML, El-Nezami H. Probiotics-mediated suppression of cancer. Curr Opin Oncol. 2017;29(1):62-72.

5. Kumar M, Verma V, Nagpal R, Kumar A, Behare P, Singh B, Aggarwal P. Anticarcinogenic effect of probiotic fermented milk and chlorophyllin on aflatoxin-B 1-induced liver carcinogenesis in rats. Br J Nutr. 2012;107(7): 1006-16.

6. Park M, Kwon B, Ku S, Ji G. The efficacy of bifidobacterium longum BORI and lactobacillus acidophilus AD031 probiotic treatment in infants with rotavirus infection. Nutrients. 2017;9(8):887.

7. Acurcio L, Sandes S, Bastos R, Sant'Anna F, Pedroso S, Reis D, Nunes Á, Cassali G, Souza M, Nicoli J. Milk fermented by Lactobacillus species from Brazilian artisanal cheese protect germ-free-mice against Salmonella Typhimurium infection. Beneficial Microb. 2017;8(4):579-88.

8. Mallina R, Craik J, Briffa N, Ahluwalia V, Clarke J, Cobb A. Probiotic containing Lactobacillus casei, Lactobacillus bulgaricus, and Streptococcus thermophiles (ACTIMEL) for the prevention of Clostridium difficile associated diarrhoea in the elderly with proximal femur fractures. J Infect Public Health. 2018;11(1):85-8.

9. Velez EM, Galdeano CM, Carmuega E, Weill R, Bonet MEB, Perdigón G. Probiotic fermented milk consumption modulates the allergic process induced by ovoalbumin in mice. Br J Nutr. 2015;114(4):566-76.

10. Nelson HS: Allergen immunotherapy now and in the future. In: Allergy \& Asthma Proceedings: 2016; 2016.

11. Fujimura T, Kinoshita J, Makino I, Nakamural K, Oyama K, Fujita $H$, Tajima H, Takamura H, Ninomiya I, Kitagawa H. Gastric cancer-state of the art in Japan. Rozhledy v chirurgii: mesicnik Ceskoslovenske chirurgicke spolecnosti. 2012; 91(6):346.

12. Hungin A, Mulligan C, Pot B, Whorwell P, Agréus L, Fracasso P, Lionis C, Mendive J. Philippart de Foy JM, Rubin G: Systematic review: probiotics in the management of lower gastrointestinal symptoms in clinical practice-an evidence-based international guide. Aliment Pharmacol Ther. 2013;38(8): 864-86.

13. Sadrzadeh-Yeganeh H, Elmadfa I, Djazayery A, Jalali M, Heshmat R, Chamary $M$. The effects of probiotic and conventional yoghurt on lipid profile in women. Br J Nutr. 2010;103(12):1778-83.

14. Kich DM, Vincenzi A, Majolo F. Volken de Souza CF, Goettert Ml: Probiotic: effectiveness nutrition in cancer treatment and prevention. Nutr Hosp. 2016; 33(6):1430-7.

15. He J, Zhang F, Han Y. Effect of probiotics on lipid profiles and blood pressure in patients with type 2 diabetes: A meta-analysis of RCTs. Medicine. 2017;96(51):e9166.

16. Abdelhamid AG, Esaam A, Hazaa MM. Cell free preparations of probiotics exerted antibacterial and antibiofilm activities against multidrug resistant $\mathrm{E}$. coli. Saudi pharmaceutical journal : SPJ : the official publication of the Saudi Pharmaceutical Society. 2018;26(5):603-7.

17. Majeed M, Nagabhushanam K, Arumugam S, Majeed S, Ali F. Bacillus coagulans MTCC 5856 for the management of major depression with irritable bowel syndrome: a randomised, double-blind, placebo controlled, multi-centre, pilot clinical study. Food Nutr Res. 2018;62.

18. Hashemian SM, Pourhanifeh MH, Fadaei S, Velayati AA, Mirzaei H, Hamblin MR. Non-coding RNAs and Exosomes: Their Role in the Pathogenesis of Sepsis. Mol Ther Nucleic Acids. 2020;21:51-74.

19. Sharma M. Apoptosis-antagonizing transcription factor (AATF) gene silencing: role in induction of apoptosis and down-regulation of estrogen receptor in breast cancer cells. Biotechnol Lett. 2013;35(10):1561-70.

20. Chen JQ, Papp G, Szodoray P, Zeher M. The role of microRNAs in the pathogenesis of autoimmune diseases. Autoimmun Rev. 2016;15(12):117180.

21. Chen $X M$, Huang QC, Yang SL, Chu YL, Yan YH, Han L, Huang Y, Huang RY. Role of Micro RNAs in the Pathogenesis of Rheumatoid Arthritis: Novel Perspectives Based on Review of the Literature. Medicine. 2015;94(31):e1326.

22. Shreiner $A B$, Kao JY, Young VB. The gut microbiome in health and in disease. Curr Opin Gastroenterol. 2015;31(1):69.

23. Rauch M, Lynch S. The potential for probiotic manipulation of the gastrointestinal microbiome. Curr Opin Biotechnol. 2012;23(2):192-201.

24. Hirayama K, Rafter J. The role of probiotic bacteria in cancer prevention. Microb Infect. 2000;2(6):681-6.

25. Guarner F. Prebiotics, probiotics and helminths: the 'natural'solution? Dig Dis. 2009;27(3):412-7.

26. Oelschlaeger TA. Mechanisms of probiotic actions-a review. Int J Med Microbiol. 2010;300(1):57-62.
27. Plaza-Diaz J, Gomez-Llorente C, Fontana L, Gil A. Modulation of immunity and inflammatory gene expression in the gut, in inflammatory diseases of the gut and in the liver by probiotics. World J Gastroenterol. 2014;20(42): 15632.

28. Lee J-Y, Chu S-H, Jeon JY, Lee M-K, Park J-H, Lee D-C, Lee J-W, Kim N-K. Effects of 12 weeks of probiotic supplementation on quality of life in colorectal cancer survivors: a double-blind, randomized, placebo-controlled trial. Dig Liver Dis. 2014;46(12):1126-32.

29. Zheng C, Chen T, Wang Y, Gao Y, Kong Y, Liu Z, Deng X. A randomised trial of probiotics to reduce severity of physiological and microbial disorders induced by partial gastrectomy for patients with gastric cancer. J Cancer. 2019;10(3):568-76.

30. Golkhalkhali B, Rajandram R, Paliany AS, Ho GF, Wan Ishak WZ, Johari CS, Chin KF. Strain-specific probiotic (microbial cell preparation) and omega-3 fatty acid in modulating quality of life and inflammatory markers in colorectal cancer patients: a randomized controlled trial. Asia Pac J Clin Oncol. 2018;14(3):179-91.

31. Tan CK, Said S, Rajandram R, Wang Z, Roslani AC, Chin KF. Pre-surgical administration of microbial cell preparation in colorectal cancer patients: a randomized controlled trial. World J Surg. 2016;40(8):1985-92.

32. Durack J, Kimes NE, Lin DL, Rauch M, McKean M, McCauley K, Panzer AR, Mar JS, Cabana MD, Lynch SV. Delayed gut microbiota development in high-risk for asthma infants is temporarily modifiable by Lactobacillus supplementation. Nat Commun. 2018;9(1):707.

33. Cabana MD, McKean M, Caughey AB, Fong L, Lynch S, Wong A, Leong R, Boushey HA, Hilton JF. Early probiotic supplementation for eczema and asthma prevention: a randomized controlled trial. Pediatrics. 2017: e20163000.

34. Del Giudice MM, Indolfi C, Capasso M, Maiello N, Decimo F, Ciprandi G. Bifidobacterium mixture (B longum BB536, B infantis M-63, B breve M-16V) treatment in children with seasonal allergic rhinitis and intermittent asthma. Ital J Pediatr. 2017:43(1):25.

35. Rutten N, Gorissen D, Eck A, Niers L, Vlieger A. Besseling-Van der Vaart I, Budding A, Savelkoul P, Van der Ent C, Rijkers G: Long term development of gut microbiota composition in atopic children: impact of probiotics. Plos One. 2015;10(9):e0137681.

36. Chowdhury T, Ali MM, Hossain MM, Singh J, Yousuf A, Yasmin F, Chowdhury FR. Efficacy of probiotics versus placebo in the prevention of necrotizing enterocolitis in preterm very low birth weight infants: a doubleblind randomized controlled trial. J Coll Physicians Surg Pak. 2016;26:770-4.

37. Lambæk ID, Fonnest G, Gormsen M, Brok J, Greisen G. Probiotics to prevent necrotising enterocolitis in very preterm infants. Dan Med J. 2016;63(3):A5203.

38. Saengtawesin V, Tangpolkaiwalsak R, Kanjanapattankul W. Effect of oral probiotics supplementation in the prevention of necrotizing enterocolitis among very low birth weight preterm infants. J Med Assoc Thai. 2014; 97(Suppl 6):S20-5

39. Lorea Baroja M, Kirjavainen P, Hekmat S, Reid G. Anti-inflammatory effects of probiotic yogurt in inflammatory bowel disease patients. Clin Exp Immunol. 2007;149(3):470-9.

40. Shadnoush M, Hosseini RS, Khalilnezhad A, Navai L, Goudarzi H, Vaezjalali M. Effects of probiotics on gut microbiota in patients with inflammatory bowel disease: a double-blind, placebo-controlled clinical trial. Korean J Gastroenterol. 2015;65(4):215-21.

41. de los Angeles Pineda M, Thompson SF, Summers K, de Leon F, Pope J, Reid G. A randomized, double-blinded, placebo-controlled pilot study of probiotics in active rheumatoid arthritis. Med Sci Monit. 2011;17(6):CR347.

42. Zamani B, Golkar HR, Farshbaf S, Emadi-Baygi M, Tajabadi-Ebrahimi M, Jafari P, Akhavan R, Taghizadeh M, Memarzadeh MR, Asemi Z. Clinical and metabolic response to probiotic supplementation in patients with rheumatoid arthritis: a randomized, double-blind, placebo-controlled trial. In J Rheum Dis. 2016;19(9):869-79.

43. Vaghef-Mehrabany E, Alipour B, Homayouni-Rad A, Sharif S-K, AsghariJafarabadi M, Zavvari S. Probiotic supplementation improves inflammatory status in patients with rheumatoid arthritis. Nutrition. 2014;30(4):430-5.

44. Wu Y-J, Wu W-F, Hung C-W, Ku M-S, Liao P-F, Sun H-L, Lu K-H, Sheu J-N, Lue K-H. Evaluation of efficacy and safety of Lactobacillus rhamnosus in children aged 4-48 months with atopic dermatitis: An 8-week, doubleblind, randomized, placebo-controlled study. J Microbiol Immunol Infect. 2017;50(5):684-92

45. Prakoeswa C, Herwanto N, Prameswari R, Astari L, Sawitri S, Hidayati A, Indramaya D, Kusumowidagdo E, Surono I. Lactobacillus plantarum IS-10506 
supplementation reduced SCORAD in children with atopic dermatitis. Beneficial Microb. 2017:8(5):833-40.

46. Rø A, Simpson MR, Rø TB, Storrø O, Johnsen R, Videm V, Øien T. Reduced Th22 cell proportion and prevention of atopic dermatitis in infants following maternal probiotic supplementation. Clin Exp Allergy. 2017;47(8): 1014-21.

47. Ishaque SM, Khosruzzaman S, Ahmed DS, Sah MP. A randomized placebocontrolled clinical trial of a multi-strain probiotic formulation (Bio-Kult ${ }^{\oplus}$ ) in the management of diarrhea-predominant irritable bowel syndrome. BMC Gastroenterol. 2018;18(1):71.

48. Preston K, Krumian R, Hattner J, de Montigny D, Stewart M, Gaddam S. Lactobacillus acidophilus CL1285, Lactobacillus casei LBC80R and Lactobacillus rhamnosus CLR2 improve quality-of-life and IBS symptoms: a double-blind, randomised, placebo-controlled study. Beneficial Microb. 2018:1-10.

49. Pinto-Sanchez MI, Hall GB, Ghajar K, Nardelli A, Bolino C, Lau JT, Martin F-P, Cominetti O, Welsh C, Rieder A. Probiotic Bifidobacterium longum NCC3001 reduces depression scores and alters brain activity: a pilot study in patients with irritable bowel syndrome. Gastroenterology. 2017;153(2):448-59 e448.

50. Fuke $N$, Aizawa $K$, Suganuma $H$, Takagi T, Naito Y. Effect of combined consumption of Lactobacillus brevis KB290 and $\beta$-carotene on minor diarrhoea-predominant irritable bowel syndrome-like symptoms in healthy subjects: a randomised, double-blind, placebo-controlled, parallel-group trial. Int J Food Sci Nutr. 2017;68(8):973-86.

51. Schnadower D, Tarr PI, Casper TC, Gorelick MH, Dean JM, O'connell KJ, Mahajan P, Levine AC, Bhatt SR, Roskind CG. Lactobacillus rhamnosus GG versus placebo for acute gastroenteritis in children. N Engl J Med. 2018; 379(21):2002-14.

52. Schnadower D, Tarr PI, Casper TC, Gorelick MH, Dean MJ, O'Connell KJ Mahajan P, Chun TH, Bhatt SR, Roskind CG. Randomised controlled trial of Lactobacillus rhamnosus (LGG) versus placebo in children presenting to the emergency department with acute gastroenteritis: the PECARN probiotic study protocol. BMJ Open. 2017;7(9):e018115.

53. Sindhu KN, Sowmyanarayanan TV, Paul A, Babji S, Ajjampur SS, Priyadarshini S, Sarkar R, Balasubramanian K, Wanke CA, Ward HD. Immune response and intestinal permeability in children with acute gastroenteritis treated with Lactobacillus rhamnosus GG: a randomized, double-blind, placebocontrolled trial. Clin Infect Dis. 2014;58(8):1107-15.

54. Allen SJ, Jordan S, Storey M, Thornton CA, Gravenor MB, Garaiova I, Plummer SF, Wang D, Morgan G: Probiotics in the prevention of eczema: a randomised controlled trial. Archives of disease in childhood 2014: archdischild-2013-305799.

55. Loo EX, Llanora GV, Lu Q, Aw MM, Lee BW, Shek LP. Supplementation with probiotics in the first 6 months of life did not protect against eczema and allergy in at-risk Asian infants: a 5-year follow-up. Int Arch allergy Immunol. 2014;163(1):25-8.

56. Singh A, Hacini-Rachinel F, Gosoniu M, Bourdeau T, Holvoet S, DoucetLadeveze R, Beaumont M, Mercenier A, Nutten S. Immune-modulatory effect of probiotic Bifidobacterium lactis NCC2818 in individuals suffering from seasonal allergic rhinitis to grass pollen: an exploratory, randomized, placebo-controlled clinical trial. Eur J Clin Nutr. 2013;67(2):161.

57. Costa D, Marteau P, Amouyal M, Poulsen LK, Hamelmann E, Cazaubiel M, Housez B, Leuillet S, Stavnsbjerg M, Molimard P. Efficacy and safety of the probiotic Lactobacillus paracasei LP-33 in allergic rhinitis: a double-blind, randomized, placebo-controlled trial (GA2LEN Study). Eur J Clin Nutr. 2014; 68(5):602.

58. Lin W-Y, Fu L-S, Lin H-K, Shen C-Y, Chen Y-J. Evaluation of the effect of Lactobacillus paracasei (HF. A00232) in children (6-13 years old) with perennial allergic rhinitis: a 12-week, double-blind, randomized, placebocontrolled study. Pediatr Neonatol. 2014;55(3):181-8.

59. Olivares M, Castillejo G, Varea V, Sanz Y. Double-blind, randomised, placebocontrolled intervention trial to evaluate the effects of Bifidobacterium longum CECT 7347 in children with newly diagnosed coeliac disease. Br J Nutr. 2014;112(1):30-40.

60. Smecuol E, Hwang HJ, Sugai E, Corso L, Chernavsky AC, Bellavite FP, Gonzalez A, Vodanovich F, Moreno ML, Vazquez H. Exploratory, randomized, double-blind, placebo-controlled study on the effects of Bifidobacterium infantis natren life start strain super strain in active celiac disease. J Clin Gastroenterol. 2013:47(2):139-47.

61. Klemenak M, Dolinšek J, Langerholc T, Di Gioia D, Mičetić-Turk D. Administration of Bifidobacterium breve Decreases the Production of TNF-a in Children with Celiac Disease. Dig Dis Sci. 2015;60(11):3386-92.
62. Nagata S, Chiba Y, Wang C, Yamashiro Y. The effects of the Lactobacillus casei strain on obesity in children: a pilot study. Beneficial Microb. 2017;8(4): $535-43$.

63. Sanchez M, Darimont C, Panahi S, Drapeau V, Marette A, Taylor VH, Doré J, Tremblay A. Effects of a diet-based weight-reducing program with probiotic supplementation on satiety efficiency, eating behaviour traits, and psychosocial behaviours in obese individuals. Nutrients. 2017;9(3):284.

64. Kim M, Kim M, Kang M, Yoo HJ, Kim MS, Ahn Y-T, Sim J-H, Jee SH, Lee JH. Effects of weight loss using supplementation with Lactobacillus strains on body fat and medium-chain acylcarnitines in overweight individuals. Food Funct. 2017;8(1):250-61.

65. Mafi A, Namazi G, Soleimani A, Bahmani F, Aghadavod E, Asemi Z. Metabolic and genetic response to probiotics supplementation in patients with diabetic nephropathy: a randomized, double-blind, placebo-controlled trial. Food Funct. 2018;9(9):4763-70.

66. Sabico S, Al-Mashharawi A, Al-Daghri NM, Yakout S, Alnaami AM, Alokail MS, McTernan PG. Effects of a multi-strain probiotic supplement for 12 weeks in circulating endotoxin levels and cardiometabolic profiles of medication naive T2DM patients: a randomized clinical trial. J Transl Med. 2017;15(1): 249.

67. Mobini R, Tremaroli V, Ståhlman M, Karlsson F, Levin M, Ljungberg M, Sohlin $M$, Bertéus Forslund $H$, Perkins R, Bäckhed F. Metabolic effects of $L$ actobacillus reuteri DSM 17938 in people with type 2 diabetes: A randomized controlled trial. Diab Obes Metab. 2017;19(4):579-89.

68. Kobyliak N, Falalyeyeva T, Mykhalchyshyn G, Kyriienko D, Komissarenko I: Effect of alive probiotic on insulin resistance in type 2 diabetes patients: randomized clinical trial. Diabetes \& Metabolic Syndrome: Clinical Research \& Reviews 2018.

69. Tonucci LB, dos Santos KMO, de Oliveira LL, Ribeiro SMR, Martino HSD. Clinical application of probiotics in type 2 diabetes mellitus: A randomized, double-blind, placebo-controlled study. Clin Nutr. 2017;36(1):85-92.

70. Ishizaki A, Bi X, Nguyen LV, Matsuda K, Pham HV, Phan CTT, Khu DTK, Ichimura H. Effects of Short-Term Probiotic Ingestion on Immune Profiles and Microbial Translocation among HIV-1-Infected Vietnamese Children. Int J Mol Sci. 2017;18(10):2185.

71. d'Ettorre G, Rossi G, Scagnolari C, Andreotti M, Giustini N, Serafino S, Schietroma I, Scheri GC, Fard SN, Trinchieri V. Probiotic supplementation promotes a reduction in T-cell activation, an increase in Th17 frequencies, and a recovery of intestinal epithelium integrity and mitochondrial morphology in ART-treated HIV-1-positive patients. Immun Inflamm Dis. 2017:5(3):244-60.

72. Villar-García J, Güerri-Fernández R, Moya A, González A, Hernández JJ, Lerma E, Guelar A, Sorli L, Horcajada JP, Artacho A. Impact of probiotic Saccharomyces boulardii on the gut microbiome composition in HIVtreated patients: a double-blind, randomised, placebo-controlled trial. PloS One. 2017;12(4):e0173802.

73. Alisi A, Bedogni G, Baviera G, Giorgio V, Porro E, Paris C, Giammaria P, Reali L, Anania F, Nobili V. Randomised clinical trial: the beneficial effects of VSL\# 3 in obese children with non-alcoholic steatohepatitis. Aliment Pharmacol Ther. 2014;39(11):1276-85.

74. Nabavi S, Rafraf M, Somi M, Homayouni-Rad A, Asghari-Jafarabadi M. Effects of probiotic yogurt consumption on metabolic factors in individuals with nonalcoholic fatty liver disease. J Dairy Sci. 2014;97(12):7386-93.

75. Sepideh A, Karim P, Hossein A, Leila R, Hamdollah M, Mohammad EG, Mojtaba S, Mohammad S, Ghader G, Seyed Moayed A. Effects of multistrain probiotic supplementation on glycemic and inflammatory indices in patients with nonalcoholic fatty liver disease: a double-blind randomized clinical trial. J Am Coll Nutr. 2016;35(6):500-5.

76. Manzhalii E, Virchenko O, Falalyeyeva T, Beregova T, Stremmel W. Treatment efficacy of a probiotic preparation for non-alcoholic steatohepatitis: A pilot trial. J Dig Dis. 2017;18(12):698-703.

77. Wai-Sun Wong V, Wong GL-H, Chim AM-L, Chu WC-W, Yeung DK-W, Li KCT, Chan HL-Y. Treatment of nonalcoholic steatohepatitis with probiotics. A proof-of-concept study. Ann Hepatol. 2015;12(2):256-62.

78. Uehara S, Monden K, Nomoto K, Seno Y, Kariyama R, Kumon H. A pilot study evaluating the safety and effectiveness of Lactobacillus vaginal suppositories in patients with recurrent urinary tract infection. Int J Antimicrob Agents. 2006;28:30-4.

79. Stapleton AE, Au-Yeung M, Hooton TM, Fredricks DN, Roberts PL, Czaja CA, Yarova-Yarovaya Y, Fiedler T, Cox M, Stamm WE. Randomized, placebocontrolled phase 2 trial of a Lactobacillus crispatus probiotic given 
intravaginally for prevention of recurrent urinary tract infection. Clin Infect Dis. 2011;52(10):1212-7.

80. Dani C, Biadaioli R, Bertini G, Martelli E, Rubaltelli FF. Probiotics feeding in prevention of urinary tract infection, bacterial sepsis and necrotizing enterocolitis in preterm infants. Neonatology. 2002;82(2):103-8.

81. Czaja CA, Stapleton AE, Yarova-Yarovaya Y, Stamm WE: Phase I trial of a Lactobacillus crispatus vaginal suppository for prevention of recurrent urinary tract infection in women. Infectious diseases in obstetrics and gynecology 2007, 2007.

82. Paineau D, Carcano D, Leyer G, Darquy S, Alyanakian M-A, Simoneau G, Bergmann J-F, Brassart D, Bornet F, Ouwehand AC. Effects of seven potential probiotic strains on specific immune responses in healthy adults: a double-blind, randomized, controlled trial. FEMS Immunol Med Microbiol. 2008;53(1):107-13.

83. Olivares M, Díaz-Ropero MP, Sierra S, Lara-Villoslada F, Fonollá J, Navas M, Rodríguez JM, Xaus J. Oral intake of Lactobacillus fermentum CECT5716 enhances the effects of influenza vaccination. Nutrition. 2007;23(3):254-60.

84. Davidson LE, Fiorino A-M, Snydman DR, Hibberd PL. Lactobacillus GG as an immune adjuvant for live-attenuated influenza vaccine in healthy adults: a randomized double-blind placebo-controlled trial. Eur J Clin Nutr. 2011;65(4):501.

85. Stensson M, Koch G, Coric S, Abrahamsson T, Jenmalm M, Birkhed D, Wendt L-K. Oral administration of Lactobacillus reuteri during the first year of life reduces caries prevalence in the primary dentition at 9 years of age. Caries Res. 2014;48(2):111-7.

86. Hedayati-Hajikand T, Lundberg U, Eldh C, Twetman S. Effect of probiotic chewing tablets on early childhood caries-a randomized controlled trial. BMC Oral Health. 2015;15(1):112.

87. Campus G, Cocco F, Carta G, Cagetti MG, Simark-Mattson C, Strohmenger L, Lingström P. Effect of a daily dose of Lactobacillus brevis CD2 lozenges in high caries risk schoolchildren. Clin Oral Investig. 2014;18(2):555-61.

88. Taipale T, Pienihäkkinen $\mathrm{K}$, Alanen $\mathrm{P}$, Jokela J, Söderling E. Administration of Bifidobacteriumanimalis subsp. lactis BB-12 in early childhood: a post-trial effect on caries occurrence at four years of age. Caries Res. 2013;47(5):364-72.

89. Kuru BE, Laleman I, Yalnızoğlu T, Kuru L, Teughels W. The Influence of a Bifidobacterium animalis Probiotic on Gingival Health: A Randomized Controlled Clinical Trial. J Periodontol. 2017;88(11):1115-23.

90. Twetman S, Pedersen AML, Yucel-Lindberg T. Probiotic supplements containing Lactobacillus reuteri does not affect the levels of matrix metalloproteinases and interferons in oral wound healing. BMC Res Notes. 2018;11(1):759.

91. Keller MK, Kragelund C. Randomized pilot study on probiotic effects on recurrent candidiasis in oral lichen planus patients. Oral Dis. 2018;24(6):1107-14.

92. Morales A, Gandolfo A, Bravo J, Carvajal P, Silva N, Godoy C, Garcia-Sesnich J, Hoare A, Diaz P, Gamonal J. Microbiological and clinical effects of probiotics and antibiotics on nonsurgical treatment of chronic periodontitis: a randomized placebo-controlled trial with 9-month follow-up. J Appl Oral Sci. 2018;26.

93. Szkaradkiewicz AK, Stopa J, Karpiński TM. Effect of oral administration involving a probiotic strain of Lactobacillus reuteri on pro-inflammatory cytokine response in patients with chronic periodontitis. Arch Immunol Ther Exp. 2014;62(6):495-500.

94. Teughels W, Durukan A, Ozcelik O, Pauwels M, Quirynen M, Haytac MC. Clinical and microbiological effects of Lactobacillus reuteri probiotics in the treatment of chronic periodontitis: a randomized placebo-controlled study. J Clin Periodontol. 2013;40(11):1025-35.

95. Ince G, Gursoy H, Ipci DS, Cakar G, Alturfan EE. YImaz S: clinical and biochemical evaluation of Lactobacillus reuteri containing lozenges as an adjunct to nonsurgical periodontal therapy in chronic periodontitis: p0199. J Clin Periodontol. 2015:42:126

96. Morales A, Carvajal P, Silva N, Hernandez M, Godoy C, Rodriguez G, Cabello R, Garcia-Sesnich J, Hoare A, Diaz PI. Clinical Effects of Lactobacillus rhamnosus in Non-Surgical Treatment of Chronic Periodontitis: A Randomized Placebo-Controlled Trial With 1-Year Follow-Up. J Periodontol. 2016:87(8):944-52

97. Keller M, Brandsborg E, Holmstrøm K, Twetman S. Effect of tablets containing probiotic candidate strains on gingival inflammation and composition of the salivary microbiome: a randomised controlled trial. Beneficial Microb. 2018;9(3):487-94

98. Alkaya B, Laleman I, Keceli S, Ozcelik O, Cenk Haytac M, Teughels W. Clinical effects of probiotics containing Bacillus species on gingivitis: a pilot randomized controlled trial. J Periodontal Res. 2017;52(3):497-504.
99. Montero E, Iniesta M, Rodrigo M, Marín MJ, Figuero E, Herrera D, Sanz M. Clinical and microbiological effects of the adjunctive use of probiotics in the treatment of gingivitis: A randomized controlled clinical trial. J Clin PeriodontolS. 2017:44(7):708-16.

100. Schlagenhauf U, Jakob L, Eigenthaler M, Segerer S, Jockel-Schneider Y, Rehn M. Regular consumption of Lactobacillus reuteri-containing lozenges reduces pregnancy gingivitis: an RCT. J Clin Periodontol. 2016;43(11):948-54

101. Iwamoto T, Suzuki N, Tanabe K, Takeshita T, Hirofuji T. Effects of probiotic Lactobacillus salivarius WB21 on halitosis and oral health: an open-label pilot trial. Oral Surg Oral Med Oral Pathol Oral Radiol Endodontol. 2010; 110(2):201-8.

102. Marchetti E, Tecco S, Santonico M, Vernile C, Ciciarelli D, Tarantino E, Marzo $\mathrm{G}$, Pennazza G. Multi-sensor approach for the monitoring of halitosis treatment via Lactobacillus brevis (CD2) — containing lozenges_-a randomized, double-blind placebo-controlled clinical trial. Sensors. 2015; 15(8):19583-96.

103. Oncel MY, Arayici S, Sari FN, Simsek GK, Yurttutan S, Erdeve O, Saygan S, Uras N, Oguz SS, Dilmen U. Comparison of Lactobacillus reuteri and nystatin prophylaxis on Candida colonization and infection in very low birth weight infants. J Maternal-Fetal Neonatal Med. 2015;28(15):1790-4.

104. Murina F, Graziottin A, Vicariotto F, De Seta F. Can Lactobacillus fermentum LF10 and Lactobacillus acidophilus LA02 in a slow-release vaginal product be useful for prevention of recurrent vulvovaginal candidiasis?: a clinical study. J Clin Gastroenterol. 2014;48:S102-5.

105. Kovachev SM, Vatcheva-Dobrevska RS. Local probiotic therapy for vaginal Candida albicans infections. Probiotics Antimicrobial Proteins. 2015;7(1):38-44.

106. Daliri EB-M, Lee BH. New perspectives on probiotics in health and disease. Food Sci Hum Wellness. 2015;4(2):56-65.

107. Soccol CR, de Souza Vandenberghe LP, Spier MR, Medeiros AP, Yamaguishi $C T$, De Dea LJ, Pandey A, Thomaz-Soccol V. The potential of probiotics: a review. Food Technol Biotechnol. 2010;48(4):413-34.

108. Organization WH. Report of a WHO consultation on xenotransplantation, Geneva, Switzerland, 28-30 October 1997. Geneva: World Health Organization; 1998.

109. Murthy N, Mathew A. Cancer epidemiology, prevention and control. Curr Sci. 2004;86(4):518-27.

110. Lopes C, Dourado A, Oliveira R. Phytotherapy and nutritional supplements on breast cancer. BioMed Res Int. 2017;2017.

111. Xue R, Cai X, Xu H, Wu S, Huang $H$. The efficacy of concurrent weekly carboplatin with radiotherapy in the treatment of cervical cancer: A metaanalysis. Gynecol Oncol. 2018;150(3):412-9.

112. Bai J, Behera M, Bruner DW. The gut microbiome, symptoms, and targeted interventions in children with cancer: a systematic review. Support Care Cancer. 2018;26(2):427-39.

113. Vétizou M, Daillère R, Zitvogel L. Gut microbiota and efficacy of cancer therapies. Biologie aujourd'hui. 2017;211(1):51-67.

114. Gao Z, Guo B, Gao R, Zhu Q, Wu W, Qin H. Probiotics modify human intestinal mucosa-associated microbiota in patients with colorectal cancer. Mol Med Rep. 2015;12(4):6119-27.

115. Li R, Helbig L, Fu J, Bian X, Herrmann J, Baumann M, Stewart AF, Müller R, Li A, Zips D, et al. Expressing cytotoxic compounds in Escherichia coli Nissle 1917 for tumor-targeting therapy. Res Microbiol. 2019;170(2):74-9.

116. Yang H, Zhao X, Tang S, Huang H, Zhao X, Ning Z, Fu X, Zhang C. Probiotics reduce psychological stress in patients before laryngeal cancer surgery. Asia-Pacific J Clin Oncol. 2016;12(1):e92-6.

117. Zhao R, Wang Y, Huang Y, Cui $Y$, Xia L, Rao Z, Zhou Y, Wu X: Effects of fiber and probiotics on diarrhea associated with enteral nutrition in gastric cancer patients: A prospective randomized and controlled trial. Medicine 2017, 96(43).

118. Zaman MK, Chin K-F, Rai V, Majid HA. Fiber and prebiotic supplementation in enteral nutrition: a systematic review and meta-analysis. World J Gastroenterol. 2015;21(17):5372.

119. McRorie JW Jr, McKeown NM. Understanding the physics of functional fibers in the gastrointestinal tract: an evidence-based approach to resolving enduring misconceptions about insoluble and soluble fiber. J Acad Nutr Diet. 2017;117(2):251-64.

120. Rayes N, Hansen S, Seehofer D, Müller AR, Serke S, Bengmark S, Neuhaus P. Early enteral supply of fiber and Lactobacilli versus conventional nutrition: a controlled trial in patients with major abdominal surgery. Nutrition. 2002; 18(7-8):609-15.

121. Williams NT. Probiotics. Am J Health-Syst Pharm. 2010;67(6):449-58. 
122. Klarin B, Molin G, Jeppsson B, Larsson A. Use of the probiotic Lactobacillus plantarum 299 to reduce pathogenic bacteria in the oropharynx of intubated patients: a randomised controlled open pilot study. Critical Care. 2008;12(6):R136

123. Ananthakrishnan AN. Epidemiology and risk factors for IBD. Nat Rev Gastroenterol Hepatol. 2015;12(4):205.

124. Sartor RB. Pathogenesis and immune mechanisms of chronic inflammatory bowel diseases. Am J Gastroenterol. 1997:92.

125. Pithadia AB, Jain S. Treatment of inflammatory bowel disease (IBD). Pharmacol Rep. 2011;63(3):629-42.

126. Gionchetti P, Rizzello F, Lammers KM, Morselli C, Sollazzi L, Davies S, Tambasco R, Calabrese C, Campieri M. Antibiotics and probiotics in treatment of inflammatory bowel disease. World J Gastroenterol. 2006;12(21):3306.

127. Oliva S, Di Nardo G, Ferrari F, Mallardo S, Rossi P, Patrizi G, Cucchiara S, Stronati L. Randomised clinical trial: the effectiveness of Lactobacillus reuteri ATCC 55730 rectal enema in children with active distal ulcerative colitis. Aliment Pharmacol Ther. 2012;35(3):327-34.

128. Kekkonen R-A, Kajasto E, Miettinen M, Veckman V, Korpela R, Julkunen I. Probiotic Leuconostoc mesenteroides ssp. cremoris and Streptococcus thermophilus induce IL-12 and IFN-gamma production. World J Gastroenterol. 2008:14(8):1192-203.

129. Sheikhi A, Giti H, Heibor MR, Jafarzadeh A, Shakerian M, Baharifar N, Niruzad F, Moghaddam AS, Kokhaei P, Baghaeifar M. Lactobacilus delbrueckii subsp. bulgaricus modulates the secretion of Th1/Th2 and Treg cell-related cytokines by PBMCs from patients with atopic dermatitis. Drug Res. 2017;67(12):724-9.

130. Karimi O, Peña AS. Bodegraven AAv: Probiotics (VSL\# 3) in arthralgia in patients with ulcerative colitis and Crohn's disease: a pilot study. Drugs Today. 2005;41(7):453-60.

131. Rossi G, Cerquetella M, Scarpona S, Pengo G, Fettucciari K, Bassotti G, Jergens A, Suchodolski J. Effects of probiotic bacteria on mucosal polyamines levels in dogs with IBD and colonic polyps: a preliminary study. Beneficial Microb. 2018;9(2):247-55.

132. Grundmann O, Yoon SL. Irritable bowel syndrome: epidemiology, diagnosis and treatment: an update for health-care practitioners. J Gastroenterol Hepatol. 2010;25(4):691-9.

133. Choung RS. Epidemiology of IBS. Gastroenterol Clin North Am. 2011:40(1):1-10.

134. Öhman L, Simrén M. Pathogenesis of IBS: role of inflammation, immunity and neuroimmune interactions. Nat Rev Gastroenterol Hepatol. 2010;7(3):163.

135. Moayyedi P, Ford AC, Talley NJ, Cremonini F, Foxx-Orenstein AE, Brandt LJ, Quigley EM. The efficacy of probiotics in the treatment of irritable bowel syndrome: a systematic review. Gut. 2010;59(3):325-32.

136. Mezzasalma V, Manfrini E, Ferri E, Sandionigi A, La Ferla B, Schiano I, Michelotti A, Nobile V, Labra M, Di Gennaro P. A randomized, double-blind, placebo-controlled trial: the efficacy of multispecies probiotic supplementation in alleviating symptoms of irritable bowel syndrome associated with constipation. BioMed Res Int. 2016;2016.

137. Choi C, Kwon J, Kim S, Myung SJ, Park K, Sohn Cl, Rhee PL, Lee K, Lee O, Jung HK. Efficacy of combination therapy with probiotics and mosapride in patients with IBS without diarrhea: a randomized, double-blind, placebo-controlled, multicenter, phase II trial. Neurogastroenterol Motil. 2015;27(5):705-16.

138. Di Sabatino A, Corazza GR. Coeliac disease. Lancet. 2009;373(9673):1480-93.

139. Brown I, Mino-Kenudson M, Deshpande V, Lauwers GY. Intraepithelial lymphocytosis in architecturally preserved proximal small intestinal mucosa: an increasing diagnostic problem with a wide differential diagnosis. Arch Pathol Lab Med. 2006;130(7):1020-5.

140. Catassi C, Gatti S, Fasano A. The new epidemiology of celiac disease. J Pediatr Gastroenterol Nutr. 2014:59:S7-9.

141. Gujral N, Freeman HJ, Thomson AB. Celiac disease: prevalence, diagnosis, pathogenesis and treatment. World J Gastroenterol. 2012;18(42):6036.

142. Marasco G, Di Biase AR, Schiumerini R, Eusebi LH, lughetti L, Ravaioli F, Scaioli E, Colecchia A, Festi D. Gut microbiota and celiac disease. Dig Dis Sci. 2016;61(6):1461-72.

143. Kverka M, Tlaskalova-Hogenova $H$. Two faces of microbiota in inflammatory and autoimmune diseases: triggers and drugs. Apmis. 2013;121(5):403-21.

144. De Palma G, Cinova J, Stepankova R, Tuckova L, Sanz Y. Pivotal Advance: Bifidobacteria and Gram-negative bacteria differentially influence immune responses in the proinflammatory milieu of celiac disease. J Leukoc Biol. 2010;87(5):765-78

145. López P, Gueimonde M, Margolles A, Suárez A. Distinct Bifidobacterium strains drive different immune responses in vitro. Int J Food Microbiol. 2010; 138(1-2):157-65.
146. He F, Morita H, Ouwehand AC, Hosoda M, Hiramatsu M. Kurisaki Ji, Isolauri E, Benno Y, Salminen S: Stimulation of the secretion of pro-inflammatory cytokines by Bifidobacterium strains. Microbiol Immunol. 2002;46(11):781-5.

147. Aloisio I, Santini C, Biavati B, Dinelli G, Cencič A, Chingwaru W, Mogna L, Di Gioia D. Characterization of Bifidobacterium spp. strains for the treatment of enteric disorders in newborns. Appl Microbiol Biotechnol. 2012;96(6):1561-76.

148. Mogna L, Del Piano M, Mogna G. Capability of the two microorganisms Bifidobacterium breve B632 and Bifidobacterium breve BR03 to colonize the intestinal microbiota of children. J Clin Gastroenterol. 2014;48:S37-9.

149. Hazards EPoB: Scientific Opinion on the maintenance of the list of QPS biological agents intentionally added to food and feed (2013 update). EFSA J 2013, 11(11):3449.

150. Jeon SG, Kayama H, Ueda Y, Takahashi T, Asahara T, Tsuji H, Tsuji NM, Kiyono H, Ma JS, Kusu T. Probiotic Bifidobacterium breve induces IL-10producing Tr1 cells in the colon. PLos Pathog. 2012;8(5):e1002714.

151. Zheng B, van Bergenhenegouwen J, Overbeek S, van de Kant HJ, Garssen J, Folkerts G, Vos P, Morgan ME, Kraneveld AD. Bifidobacterium breve attenuates murine dextran sodium sulfate-induced colitis and increases regulatory T cell responses. Plos One. 2014;9(5):e95441.

152. Yudoh K, Matsuno H, Nakazawa F, Yonezawa T, Kimura T. Reduced expression of the regulatory CD4+ T cell subset is related to Th1/Th2 balance and disease severity in rheumatoid arthritis. Arthritis Rheum. 2000;43(3):617-27.

153. Lauret E, Rodrigo L. Celiac disease and autoimmune-associated conditions. BioMed Res Int. 2013;2013.

154. Quagliariello A, Aloisio I, Bozzi Cionci N, Luiselli D, D'Auria G, Martinez-Priego L, Pérez-Villarroya D, Langerholc T, Primec M, Mičetić-Turk D. Effect of Bifidobacterium breve on the intestinal microbiota of coeliac children on a gluten free diet: a pilot study. Nutrients. 2016;8(10):660.

155. Klingspor S, Bondzio A, Martens H, Aschenbach JR, Bratz K, Tedin K, Einspanier R. Lodemann U: <i>Enterococcus faecium</i> NCIMB 10415 Modulates Epithelial Integrity, Heat Shock Protein, and Proinflammatory Cytokine Response in Intestinal Cells. Mediators Inflamm. 2015;2015:304149.

156. Firestein GS. Evolving concepts of rheumatoid arthritis. Nature. 2003; 423(6937):356.

157. Mclnnes IB, Schett G. Cytokines in the pathogenesis of rheumatoid arthritis. Nat Rev Immunol. 2007;7(6):429.

158. Alamanos Y, Drosos AA. Epidemiology of adult rheumatoid arthritis. Autoimmun Rev. 2005:4(3):130-6.

159. Lipsky PE, van der Heijde DM, St. Clair EW, Furst DE, Breedveld FC, Kalden JR, Smolen JS, Weisman M, Emery P, Feldmann M. Infliximab and methotrexate in the treatment of rheumatoid arthritis. N Engl J Med. 2000; 343(22):1594-602

160. Schnabel A, Gross WL: Low-dose methotrexate in rheumatic diseases_efficacy, side effects, and risk factors for side effects. In: Seminars in arthritis and rheumatism: 1994: Elsevier; 1994: 310-327.

161. Borchers AT, Selmi C, Meyers FJ, Keen CL, Gershwin ME. Probiotics and immunity. J Gastroenterol. 2009:44(1):26-46.

162. Mandel DR, Eichas K, Holmes J. Bacillus coagulans: a viable adjunct therapy for relieving symptoms of rheumatoid arthritis according to a randomized, controlled trial. BMC Complement Altern Med. 2010;10(1):1

163. Alipour B, Homayouni-Rad A, Vaghef-Mehrabany E, Sharif SK, VaghefMehrabany L, Asghari-Jafarabadi M, Nakhjavani MR, Mohtadi-Nia J. Effects of $L$ actobacillus casei supplementation on disease activity and inflammatory cytokines in rheumatoid arthritis patients: a randomized double-blind clinical trial. Int J Rheum Dis. 2014;17(5):519-27.

164. Hatakka K, Martio J, Korpela M, Herranen M, Poussa T, Laasanen T, Saxelin M, Vapaatalo H, Moilanen E, Korpela R. Effects of probiotic therapy on the activity and activation of mild rheumatoid arthritis-a pilot study. Scand J Rheumatol. 2003;32(4):211-5.

165. Jansson MD, Lund AH. MicroRNA and cancer. Mol Oncol. 2012;6(6):590-610.

166. Maes OC, Chertkow HM, Wang E, Schipper HM. MicroRNA: implications for Alzheimer disease and other human CNS disorders. Curr Genomics. 2009: 10(3):154-68.

167. Jinnin M. microRNA in autoimmune disorders. Nihon Rinsho Men'eki Gakkai kaishi=Japanese journal of clinical immunology. 2011;34(6):439-46.

168. Croce CM. Causes and consequences of microRNA dysregulation in cancer. Nat Rev Genet. 2009;10(10):704

169. Hecker M, Thamilarasan M, Koczan D, Schröder I, Flechtner K, Freiesleben S, Füllen $\mathrm{G}$, Thiesen $\mathrm{H}-\mathrm{J}$, Zettl U. MicroRNA expression changes during interferon-beta treatment in the peripheral blood of multiple sclerosis patients. Int J Mol Sci. 2013;14(8):16087-110. 
170. Wang J, Huang W, Wu Y, Hou J, Nie Y, Gu H, Li J, Hu S, Zhang H. MicroRNA193 pro-proliferation effects for bone mesenchymal stem cells after lowlevel laser irradiation treatment through inhibitor of growth family, member 5. Stem Cells Dev. 2012;21(13):2508-19.

171. Janssen HL, Reesink HW, Lawitz EJ, Zeuzem S, Rodriguez-Torres M, Patel K, van der Meer AJ, Patick AK, Chen A, Zhou Y. Treatment of HCV infection by targeting microRNA. N Engl J Med. 2013;368(18):1685-94.

172. Chen Q, Tong C, Ma S, Zhou L, Zhao L, Zhao X. Involvement of microRNAs in probiotics-induced reduction of the cecal inflammation by Salmonella typhimurium. Front Immunol. 2017;8:704.

173. Heydari Z, Rahaie M, Alizadeh AM, Agah S, Khalighfard S, Bahmani S. Effects of Lactobacillus acidophilus and Bifidobacterium bifidum Probiotics on the Expression of MicroRNAs 135b, 26b, 18a and 155, and Their Involving Genes in Mice Colon Cancer. Probiotics Antimicrob Proteins. 2018:1-8.

174. Kreuzer-Redmer S, Bekurtz JC, Arends D, Bortfeldt R, Kutz-Lohroff B, Sharbati S, Einspanier R, Brockmann GA. Feeding of Enterococcus faecium NCIMB 10415 leads to intestinal miRNA-423-5p-induced regulation of immunerelevant genes. Appl Environ Microbiol. 2016;82(8):2263-9.

175. Simpson MR, Brede G, Johansen J, Johnsen R, Storrø O, Sætrom P, Øien T. Human breast milk miRNA, maternal probiotic supplementation and atopic dermatitis in offspring. Plos One. 2015;10(12):e0143496.

176. Zhao H, Zhao C, Dong Y, Zhang M, Wang Y, Li F, Li X, McClain C, Yang S, Feng $W$. Inhibition of miR122a by Lactobacillus rhamnosus GG culture supernatant increases intestinal occludin expression and protects mice from alcoholic liver disease. Toxicol Lett. 2015;234(3):194-200.

177. Sabharwal H, Cichon C, Ölschläger TA, Sonnenborn U, Schmidt MA: Interleukin-8, CXCL1, and MicroRNA miR-146a responses to probiotic Escherichia coli nissle 1917 and enteropathogenic E. coli in human intestinal epithelial T84 and Monocytic THP-1 cells after apical or basolateral infection. Infect Immun 2016, 84(9):2482-2492

178. Kalani M, Hodjati H, Khanian MS, Doroudchi M. Lactobacillus acidophilus increases the anti-apoptotic micro RNA-21 and decreases the proinflammatory micro RNA-155 in the LPS-treated human endothelial cells. Probiotics Antimicrobial Proteins. 2016;8(2):61-72.

179. Rodríguez-Nogales A, Algieri F, Garrido-Mesa J, Vezza T, Utrilla MP, Chueca N, Garcia F, Olivares M, Rodríguez-Cabezas ME, Gálvez J. Differential intestinal antiinflammatory effects of Lactobacillus fermentum and Lactobacillus salivarius in DSS mouse colitis: impact on microRNAs expression and microbiota composition. Mol Nutr Food Res. 2017;61(11):1700144.

180. Veltman K, Hummel S, Cichon C, Sonnenborn U, Schmidt MA. Identification of specific miRNAs targeting proteins of the apical junctional complex that simulate the probiotic effect of E. coli Nissle 1917 on T84 epithelial cells. int J Biochem Cell Biol. 2012;44(2):341-9.

181. Vahed SZ, Barzegari A, Saadat YR, Goreyshi A, Omidi Y. Leuconostoc mesenteroides-derived anticancer pharmaceuticals hinder inflammation and cell survival in colon cancer cells by modulating NF-KB/AKT/PTEN/MAPK pathways. Biomed Pharmacother. 2017;94:1094-100.

182. Ceccarelli G, Fratino M, Selvaggi C, Giustini N, Serafino S, Schietroma I, Corano Scheri G, Pavone P, Passavanti G, Alunni Fegatelli D. A pilot study on the effects of probiotic supplementation on neuropsychological performance and micro RNA-29a-c levels in antiretroviral-treated HIV-1infected patients. Brain Behav. 2017;7(8):e00756.

183. Giahi L, Aumueller E, Elmadfa I, Haslberger A. Regulation of TLR4, p38 MAPkinase, IKB and miRNAs by inactivated strains of lactobacilli in human dendritic cells. Beneficial Microb. 2012;3(2):91-8.

184. Nogales AR, Algieri F, Garrido-Mesa J, Vezza T, Utrilla MP, Chueca N, Fernandez-Caballero JA, García F, Rodriguez-Cabezas ME, Gálvez J. The administration of Escherichia coli Nissle 1917 ameliorates development of DSS-induced colitis in mice. Front Pharmacol. 2018;9:468.

185. Taibi A, Singh N, Chen J, Arioli S, Guglielmetti S, Comelli EM. Time-and strain-specific downregulation of intestinal EPAS1 via miR-148a by Bifidobacterium bifidum. Mol Nutr Food Res. 2017;61(5):1600596.

186. Li C, Jia L, Yu Y, Jin L. Lactic acid induced microRNA-744 enhances motility of SiHa cervical cancer cells through targeting ARHGAP5. Chem Biol Interact. 2019;298:86-95.

187. Liu Z, Tian Y, Jiang Y, Chen S, Liu T, Moyer MP, Qin H, Zhou X. Protective Effects of Let-7b on the Expression of Occludin by Targeting P38 MAPK in Preventing Intestinal Barrier Dysfunction. Cell Physiol Biochem. 2018;45(1):343-55.

188. Starke I, Zentek J, Vahjen W. Effects of the probiotic Enterococcus faecium NCIMB 10415 on selected lactic acid bacteria and enterobacteria in coculture. Beneficial Microb. 2014;6(3):345-52.
189. Siepert B, Reinhardt N, Kreuzer S, Bondzio A, Twardziok S, Brockmann G, Nöckler K, Szabó I, Janczyk P, Pieper R. Enterococcus faecium NCIMB 10415 supplementation affects intestinal immune-associated gene expression in post-weaning piglets. Vet Immunol Immunopathol. 2014;157(1-2):65-77.

190. Schultz M. Clinical use of E. coli Nissle 1917 in inflammatory bowel disease. Inflamm Bowel Dis. 2008;14(7):1012-8.

191. Bandiera S, Pfeffer S, Baumert TF. Zeisel MB: miR-122-a key factor and therapeutic target in liver disease. J Hepatol. 2015;62(2):448-57.

192. Lou G, Yang Y, Liu F, Ye B, Chen Z, Zheng M, Liu Y. MiR-122 modification enhances the therapeutic efficacy of adipose tissue-derived mesenchymal stem cells against liver fibrosis. J cell Mol Med. 2017;21(11):2963-73.

193. Sadri NJ, Moghoofei M, Salmaninejad A, Bahmanpour Z, Karimzadeh M, Nasiri M, Mirzaei H, Pourhanifeh M, Bokharaei-Salim F, Mirzaei H. Pathogenic role of exosomes and microRNAs in HPV-mediated inflammation and cervical cancer: A review. Int J Cancer. 2019.

194. Goetze K, Walenta S, Ksiazkiewicz M, Kunz-Schughart LA, Mueller-Klieser W. Lactate enhances motility of tumor cells and inhibits monocyte migration and cytokine release. Int J Oncol. 2011;39(2):453-63.

195. Walenta S, Schroeder T, Mueller-Klieser W. Lactate in solid malignant tumors: potential basis of a metabolic classification in clinical oncology. Curr Med Chem. 2004;11(16):2195-204.

196. Li Y, Deng X, Zeng X, Peng X. The role of mir-148a in cancer. J Cancer. 2016 7(10):1233.

197. Sepehri Z, Kiani Z, Kohan F, Alavian SM, Ghavami S. Toll like receptor 4 and hepatocellular carcinoma; A systematic review. Life Sci. 2017;179:80-7.

198. Kuzmich N, Sivak K, Chubarev V, Porozov Y, Savateeva-Lyubimova T, Peri F. TLR4 signaling pathway modulators as potential therapeutics in inflammation and sepsis. Vaccines. 2017;5(4):34.

199. Cuenda A, Rousseau S. p38 MAP-kinases pathway regulation, function and role in human diseases. Biochimica et Biophysica Acta (BBA)-Molecular. Cell Res. 2007;1773(8):1358-75.

200. Stiles ME. Bacteriocins produced by Leuconostoc species. J Dairy Sci. 1994; 77(9):2718-24

\section{Publisher's Note}

Springer Nature remains neutral with regard to jurisdictional claims in published maps and institutional affiliations.
Ready to submit your research? Choose BMC and benefit from:

- fast, convenient online submission

- thorough peer review by experienced researchers in your field

- rapid publication on acceptance

- support for research data, including large and complex data types

- gold Open Access which fosters wider collaboration and increased citations

- maximum visibility for your research: over $100 \mathrm{M}$ website views per year

At $\mathrm{BMC}$, research is always in progress.

Learn more biomedcentral.com/submissions 